\title{
The influence of Congo River discharges in the surface and deep layers of the Gulf of Guinea
}

\author{
Annick Vangriesheim ${ }^{\mathrm{a},}{ }^{*}$, Catherine Pierre ${ }^{\mathrm{b}}$, Alain Aminot $^{\mathrm{a}}$, Nicolas Metzl ${ }^{\mathrm{b}}$, François Baurand ${ }^{\mathrm{c}}$ \\ and Jean-Claude Caprais ${ }^{a}$
}

\author{
a Ifremer, DEEP/LEP, B.P. 70, 29280 Plouzané, France \\ ${ }^{\mathrm{b}}$ LOCEAN, Université Pierre et Marie Curie, 4 Place Jussieu, 75252 Paris Cedex 05, France \\ ${ }^{c}$ Centre IRD de Bretagne, B.P. 70, 29280 Plouzané, France
}

\author{
*: Corresponding author : Annick Vangriesheim, Tel.: +33 2982242 98; fax: +33 29822 47 57, email \\ address : Annick.Vangriesheim@ifremer.fr
}

\begin{abstract}
:
The main feature of the Congo-Angola margin in the Gulf of Guinea is the Congo (ex-Zaire) deep-sea fan composed of a submarine canyon directly connected to the Congo River, a channel and a [sediment] lobe area. During the multi-disciplinary programme called BIOZAIRE conducted by Ifremer from 2000 to 2005, two CTD-O2 sections with discrete water column samples were performed (BIOZAIRE3 cruise: 2003-2004) to study the influence of the Congo River discharges, both in the surface layer and in the deep and near-bottom layers.
\end{abstract}

The surface layer water is greatly diluted with river water that has a heavy particle load. The deep layer is affected by episodic turbidity currents that flow in the deep Congo channel and reach deep areas far from the coast. Previous studies revealed deep anomalies in oxygen (deficit) and nutrient (excess) concentrations at not, vert, similar4000 $\mathrm{m}$ depth and assumed that they resulted from mineralisation of the particulate organic matter from the Congo River. The BIOZAIRE3 sections were designed to explore these phenomena in more detail near the Congo channel. Oxygen and nutrients were measured as well as additional parameters, including stable isotopes of oxygen and carbon, dissolved inorganic carbon and $\mathrm{pH}$.

For the surface layer, the effect of the Congo River was studied with reference to salinity. Deviations from the theoretical dilution of various inorganic solutes suggested the occurrence of mineralisation and consumption processes.

For the deep layer, the network of CTD-O2 stations gave a more detailed description of the deep anomalies than in previous studies. From the east-west section, anomalies appeared on the bottom at $4000 \mathrm{~m}$ depth and became slightly shallower when they spread to the west. They were also present north and south on the bottom along the $4000 \mathrm{~m}$ isobath. In these deep waters, the decrease in the $\delta 13 \mathrm{C}$ values of dissolved inorganic carbon confirmed that the mineralisation of organic matter plays a role in generating these anomalies. The location of the origin of this deep anomaly is debated. Here, arguments are given in favour of mineralisation of the particulate organic matter input that overflows from the Congo channel at not, vert, similar $4000 \mathrm{~m}$ depth during turbidity current events. Other authors suggest that this input comes from downslope particle transport.

Anomalies of the same origin, but weaker, also occurred deeper on the Congo lobe, where the Congo channel ends, but with a significant $\mathrm{pH}$ decrease on the bottom which was not seen at $4000 \mathrm{~m}$ depth.

Keywords: Gulf of Guinea; Congo canyon; Oxygen anomaly; Nutrient anomaly; Stable isotopes; DIC 


\section{Introduction}

From 2000 to 2005, the multi-disciplinary BIOZAIRE programme conducted by the French Research Institute for Exploitation of the Sea (Ifremer) aimed to study deep-sea benthic ecosystems on the Congo-Angola margin in the Gulf of Guinea (Sibuet et al., this volume). This area (Fig. 1) holds particular interest because different kinds of environments occur due to a variety of specific influences (Congo River, slope, cold seeps). Current knowledge on the geology of the Congo-Angola margin is summarised in (Savoye et al., this volume).

The main noteworthy feature of this area is the Congo (ex-Zaire) deep-sea fan. The Congo River is the second most voluminous river in the world after the Amazon River with an average flow of $42800 \mathrm{~m}^{3} \mathrm{~s}^{-1}$ and covers a continental drainage area of $3.7 \times 10^{6} \mathrm{~km}^{2}$ (Savoye et al., this volume). Although it has a relatively low annual sediment discharge $\left(55 \times 10^{6} \mathrm{t} \mathrm{yr}^{-1}\right)$ compared to that of the Amazon River, the Congo River supplies a large volume of particulate and dissolved organic matter to the ocean, both in the surface plume and at the sea bottom through the turbidity activity in the Congo canyon.

Several studies were conducted by the Netherlands Institute for Sea Research (NIOZ) in the 1970s-1980s to investigate the Congo discharge area (Eisma and Van Bennekom, 1978; Van Bennekom and Berger, 1984). These studies, along with further hydrographic studies, focused on the permanent deep-sea anomalies (at $\sim 4000 \mathrm{~m}$ depth) observed in oxygen and nutrient concentrations along the margin in the Gulf of Guinea. Van Bennekom and Berger (1984) concluded that the decrease in oxygen combined with the increase in nutrients could be explained by the oxidation of particulate organic matter brought by the Congo River. Warren and Speer (1991) noted the southward propagation of these anomalies. Arhan et al. (1998) and (Oudot et al., 1998), also observed these anomalies to the north. Van Bennekom (1996) suggested the role of upward diffusion of silicate from the Congo River sediments rather than the vertical settling of the biogenic silica on the continental slope.

The Congo canyon is directly connected to the river mouth; it cuts deeply into the shelf and the continental slope and feeds a $1250 \mathrm{~km}$ long meandering valley where the sediment input is transported by episodic turbidity currents (Savoye et al., 2000; Babonneau et al., 2002; Savoye et al., this volume). These authors reported that the depth of the valley is greater in the upper (eastern) part of the channel and decreases westward away from the coast. Their studies have shown that the sediments transported in the Congo channel by turbidity currents cannot flow out of the valley when it is too deep: outflow can only occur at around $4000 \mathrm{~m}$ depth (Dennielou and Jouanneau, 2003) when the thickness of the turbidity current is greater than the height of the valley. During a direct observation of a turbidity current at $\sim 4000 \mathrm{~m}$ depth (Khripounoff et al., 2003), a particle outflow event was recorded $13 \mathrm{~km}$ away from the channel in a sediment trap located at $30 \mathrm{~m}$ above the seafloor. Another turbidity current was directly observed in 2004 along the Congo channel but without overflow travelling to the same distance (Vangriesheim et al, this volume), showing the irregularity of these events. Moreover, the Equalant cruise conducted in 2000 by the French Research Institute for Development (IRD, ex-Orstom), did CTD sections in the same area. The turbidity profiles (Fig. 2) showed that the bottom nepheloid layer increased in particle concentration, but not in thickness, from offshore to nearshore stations and near the channel axis. This pattern would be consistent with lower overflow thickness at shallower depths. Although anomalies may be observed elsewhere along the margin, we (Braga et al., 2004) suggested that a relationship exists between the intensity of the turbidity current overflow and the occurrence of the oxygen anomaly at $\sim 4000 \mathrm{~m}$ depth in this area. To explain why the deep oxygen anomalies were not observed shallower than $4000 \mathrm{~m}$ along the margin, we (Braga et al., 2004) hypothesised that they come from the Congo channel particle overflow rather than from particles sliding along the margin, at least in the Congo channel area. 
The water masses in the Gulf of Guinea have been described by Warren and Speer (1991), Arhan et al. (1998), Stramma and England (1999), Ternon et al. (2001). A brief summary is given hereafter.

The surface waters are strongly influenced by the Congo River discharge which induces a thin layer of very low salinity water, between ca. 15 and 35, at the mouth and at the plume limit $\sim 700 \mathrm{~km}$ offshore, respectively. Near the coast, the plume first spreads to the WNW. Offshore, it spreads to the west and, even further offshore, to the south (Eisma and Van Bennekom, 1978). There is also seasonal variability in the surface salinity distribution. A subsurface salinity maximum marks the upper part (at $\sim 100 \mathrm{~m}$ ) of the South Atlantic Central Water (SACW), the lower part of which (at ca. $500 \mathrm{~m}$ ) is marked by the salinity minimum of the Antarctic Intermediate Water (AAIW) around 500-1000 m. Toward 400-500 m in the SACW, oxygen is highly depleted (Oxygen Minimum Zone), nutrients and $\mathrm{CO}_{2}$ increase and $\mathrm{pH}$ decreases, due to mineralisation of organic matter coming from surface primary production. In contrast, the AAIW is marked by an oxygen maximum due to its recent contact with the atmosphere. Between $1500 \mathrm{~m}$ and $4000 \mathrm{~m}$ is found the North Atlantic Deep Water (NADW) divided in upper, middle and lower deep layers and characterised by maximum of salinity (second to that of the SACW), of oxygen and of $\mathrm{pH}$. The NADW enters the Gulf of Guinea from the north-western Atlantic basin through the Romanche Fracture Zone (across the Mid-Atlantic Ridge at $\sim 0^{\circ} \mathrm{N}$ ) and then spreads in the Gulf of Guinea with a cyclonic gyre. Deeper than $4000 \mathrm{~m}$, lies a water layer with lower salinity, oxygen and $\mathrm{pH}$, the Guinea Basin Bottom Water (GBBW) resulting from the mixing of the Lower North Atlantic Deep Water (LNADW) with the Antarctic Bottom Water (AABW) when they flow across the Romanche Fracture Zone.

One objective of the BIOZAIRE programme (Sibuet et al., this volume) was to compare the benthic fauna in areas under the influence of cold seeps or of input from the Congo River with the benthic fauna in areas assumed not to be under either of these influences. It was our purpose to study influences of the Congo River discharge in the water column in these different areas with a set of CTD- $\mathrm{O}_{2}$ stations that was performed during the BIOZAIRE3 cruise (December 2003-January 2004). The network of stations covered the area influenced by the freshwater discharge of the Congo River and was particularly devoted to the study of production and mineralisation of organic matter in the surface waters, in the $4000 \mathrm{~m}$ layer and in the near-bottom water layer.

\section{Materials and methods}

To investigate the water column around the sites chosen by the BIOZAIRE programme for studying benthic fauna (Sibuet et al., this volume), two $\mathrm{CTD}-\mathrm{O}_{2}$ sections were set up (Table 1; Fig. 1), one section (stations 22 to 38) above the Congo canyon and channel axis (along $\sim 5^{\circ} 50^{\prime} \mathrm{S}$, then toward the lobe of the Congo channel) to study the offshore extension of the $4000 \mathrm{~m}$ depth anomalies, the other section (stations 2 to 19) along the $\sim 4000 \mathrm{~m}$ isobath to the north and to the south to study the lateral extension of the $4000 \mathrm{~m}$ depth anomalies on each side of the channel (from $2^{\circ} 45^{\prime} \mathrm{S}$ to $9^{\circ} \mathrm{S}$ ). Except for stations 6 to 19 , stations were located at each 30' of longitude. Stations 6 to 19 were located at each 30' of latitude. Thus, the distance between stations was roughly 30 miles (see $\mathrm{CTD}-\mathrm{O}_{2}$ locations on Table 1). Some additional CTD-O ${ }_{2}$ stations were performed in the specific sites chosen for intensive biological studies (sites ZD, ZD', Regab, Tête also seen on Fig. 1).

The CTD $-\mathrm{O}_{2}$ equipment (SBE $911^{+}$) was mounted with sensors of pressure, temperature, conductivity, oxygen, fluorescence and turbidity and 30 bottles of 8 litres. The profiles were performed down to ca. $15 \mathrm{~m}$ above the bottom where the first samples were taken. Additional samples were taken at $50 \mathrm{~m}$ and $100 \mathrm{~m}$ above this depth, then at selected pressures depending on the water depth with more vertical resolution around $4000 \mathrm{~m}$ and close to the 
surface. Fluorescence and turbidity records are not presented in this paper due to some noise and problems that appeared in the data

In addition to measuring oxygen and nutrient concentrations, we also measured the oxygen isotope composition of water and the carbon isotope composition of the dissolved inorganic carbon (DIC), as well as DIC itself at selected stations (Table 1). These water samples were also used to analyse biogenic silica (Ragueneau et al., this volume), elemental chemistry and metallic compounds (not presented here). Moreover, a lowered Acoustic Doppler Current Profiler $(75 \mathrm{kHz})$ was installed on the CTD to measure the currents in the whole water column during the CTD measurements (not shown in this paper).

The continuous oxygen profiles from the CTD-O $\mathrm{O}_{2}$ casts were calibrated by on-board analysis of discrete water samples using the Winkler method (Aminot and Kérouel, 2004) with an accuracy of $5 \mu \mathrm{mol} / \mathrm{kg}$ (10 $\mathrm{ml}$ sample).

Salinity was calibrated by on-board analysis of discrete water samples with an Autosal salinometer (Practical Salinity Scale 1978; accuracy of 0.0005).

Nutrients were simultaneously analysed on-board with an AutoAnalyzer A3 Bran-Luebbe ${ }^{\circledR}$ with accuracies of $0.15 \mu \mathrm{mol} / \mathrm{kg}$ for silicic acid (thereafter named silicate), $0.5 \mu \mathrm{mol} / \mathrm{kg}$ for nitrate and $0.025 \mu \mathrm{mol} / \mathrm{kg}$ for phosphate.

For $\mathrm{pH}$ determination, $10 \mathrm{ml}$ samples were collected in glass bottles, closed with ground glass stoppers without entrapping air, and left standing for 1-3 $\mathrm{h}$ in the laboratory in order to reach ambient temperature $\left(25 \pm 2{ }^{\circ} \mathrm{C}\right)$. Measurement was carried out on-board using the electrochemical method on the National Bureau of Standard (NBS) scale. The combined electrode (Metrohm, ref 6.0239.100; glass $+\mathrm{Ag} / \mathrm{AgCl}$ reference with ground glass junction) was connected to a Metrohm $713 \mathrm{pH}$ meter. Calibration was performed for each station at $25^{\circ} \mathrm{C}$, using NBS standard solutions at pH ca. 7 and ca. 9 (Metrohm ref 6.230.110 and 6.307 .120 , respectively). $\mathrm{pH}$ and temperature in seawater samples were recorded when the display stabilised after $30 \mathrm{~s}$. pH data were normalised at $25^{\circ} \mathrm{C}$ and atmospheric pressure. Reproducibility of the method was $\pm 0.01 \mathrm{pH}$. Because NBS pH data depend somewhat on electrode characteristics, they were mainly used as relative tracers, so values should not be compared with data referring to other seawater pH scales (e.g. (Ternon et al., 2001).

Discrete samples for analysis of DIC and Total Alkalinity (TA) were collected over the whole water column at selected stations and from the surface water at most stations (Table 1). To stop biological activity, the samples were poisoned with a saturated $\mathrm{HgCl}_{2}$ solution. The water samples were analysed at the LOCEAN/IPSL laboratory in Paris. DIC and TA concentrations were both obtained using potentiometric titration derived from the method developed by Edmond (1970) using a closed cell (Corbière et al., 2007). The calculation of the equivalence point was estimated using a non-linear regression method (DOE, 1994). For calibration, we used Certified Reference Material (CRM, Batch\#58) provided by Prof A. Dickson (Scripps Institution of Oceanography, San Diego, USA). The accuracy of DIC and TA for the CRM are estimated to be $\pm 2 \mu \mathrm{mol} / \mathrm{kg}$. However, judging from the classical TA/Salinity relationship (Millero et al., 1998), we identified a significant shift in our TA data. Therefore, we will only discuss the DIC observations along with other geochemical properties.

Water samples dedicated to stable isotope analysis were collected at each station in surface and bottom waters and in the whole water column at 14 selected stations (Table 1). The samples for ${ }^{18} \mathrm{O}$ measurements were stored in $20 \mathrm{ml}$ glass bottles; the samples for ${ }^{13} \mathrm{C}$ measurements were stored in $125 \mathrm{ml}$ glass bottles and poisoned with $1 \mathrm{ml}$ of a saturated solution of $\mathrm{HgCl}_{2}$ immediately after collection to stop bacterial activity. We analysed $\mathrm{CO}_{2}$ preparations using the $\mathrm{CO}_{2}$-water equilibration method of Epstein and Mayeda (1953) to measure the oxygen isotope composition of water. We used the acid extraction method on DIC (Kroopnick, 1974) to measure the carbon isotope composition of the DIC.

The isotopic compositions are expressed in the conventional $\delta^{18} \mathrm{O}$ and $\delta^{13} \mathrm{C}$ notations $(\delta=$ [(Rs/Rr) -1] x 1000, where $\mathrm{R}={ }^{18} \mathrm{O} /{ }^{16} \mathrm{O}$ or ${ }^{13} \mathrm{C} /{ }^{12} \mathrm{C}$, respectively, in the sample and the reference). The $\delta^{18} \mathrm{O}$ reference was the mean ocean water V-SMOW (Craig, 1961) and the $\delta^{13} \mathrm{C}$ reference was V-PDB (Craig, 1957). The stable isotope measurements of water 
samples were processed in the LOCEAN/IPSL laboratory. The $\mathrm{CO}_{2}$ gas produced during the sample preparation was analysed with a dual inlet-triple collector mass spectrometer (VGSira 9 ); the analytical precision $2 \sigma$ was $0.01 \%$ and the analytical reproducibility was $0.02 \%$ for ${ }^{18} \mathrm{O}$ and ${ }^{13} \mathrm{C}$ measurementș.

\section{Results}

\subsection{Surface waters}

The results of the various parameters measured in the surface waters during the CTD-O sections helped to highlight their relationships with salinity in the area influenced by the Congo River surface plume. These data provide a detailed chemical description of the very diluted waters and complement the more offshore data obtained by others.

The Apparent Oxygen Utilisation (AOU $=$ oxygen concentration at saturation minus measured oxygen) was calculated using the equation of (Benson and Krause, 1984) to evaluate oxygen consumption ( $\mathrm{AOU}>0$ ) or oxygen production $(\mathrm{AOU}<0)$ in the surface ocean waters that are mostly controlled by respiration and photosynthesis, respectively. Both the AOU-salinity relation and the longitudinal distributions of AOU (Fig. 3) indicate that respiration (i.e. mineralisation) was limited to waters with salinity lower than 30 from the Congo River plume that were located along $\sim 5^{\circ} 50^{\circ} \mathrm{S}$ latitude and not further than $10^{\circ} \mathrm{E}$ longitude, whereas photosynthesis (i.e. production) dominated in all stations.

In surface waters, variation in $\delta^{18} \mathrm{O}$ is used to characterise evaporation $\left(\delta^{18} \mathrm{O}\right.$ and salinity increase) and dilution ( $\delta^{18} \mathrm{O}$ and salinity decrease), (Craig and Gordon, 1965). In the deep layers, the $\delta^{18} \mathrm{O}$ values characterise the different water masses and may be considered as a conservative tracer of circulation. The $\delta^{13} \mathrm{C}$ value of the dissolved inorganic carbon represents a tracer of physical and biogeochemical processes involved in the carbon cycle (Pierre et al., 1991). Its variations are mainly controlled by the budget of the production $\left(\delta^{13} \mathrm{C}\right.$ increases) and mineralisation $\left(\delta^{13} \mathrm{C}\right.$ decreases) of organic matter. These productionmineralisation processes also induce the decrease-increase of the DIC concentrations and thus help to characterize them, as well as $\mathrm{pH}$ that decreases with the mineralisation due to weak acid production.

The following results illustrate the surface water dilution with the Congo River fresh water through the distribution of stable isotopes in water $\left(\delta^{18} \mathrm{O}\right)$ and in $\mathrm{DIC}\left(\delta^{13} \mathrm{C}\right)$, nutrients and DIC and through each parameter's relationship with salinity. Although data on the composition of the Congo River were not available, it can be deduced by extrapolating the linear regressions to a salinity value of zero.

The linear relation between the $\delta^{18} \mathrm{O}$ and salinity values of surface waters was characterised by a slope of 0.1 and an origin of $-2.9 \%$ and described the dilution effect by the fresh water discharge of the Congo River (Fig. 4). There was also a linear relation between $\delta^{13} \mathrm{C}$ and salinity values of surface waters with a slope of 0.1 and an origin of $-2.9 \%$ o that similarly describes the mixing of surface ocean waters with the Congo River. The low $\delta^{13} \mathrm{C}$ value of the Congo River indicates that it contains inorganic carbon coming from the oxidation of terrestrial organic matter (Fig. 4). In fact, of the area studied during the BIOZAIRE3 cruise, the surface waters that were not affected by the Congo River dilution (salinities $>35, \delta^{18} \mathrm{O}$ ca. $0.8 \%$ o, $\delta^{13} \mathrm{C}=1.25$ to $1.54 \%$ ) were located south of $7 \mathrm{~S}$. The highest dilution was recorded at station 24 that was located about $150 \mathrm{~km}$ away from the Congo River mouth (at $11^{\circ} \mathrm{E}$ ), where salinity, $\delta^{18} \mathrm{O}$ and $\delta^{13} \mathrm{C}$ values reached $22.93,-0.64 \%$ and $-0.22 \%$ respectively: a simple mass balance calculation indicates that the surface ocean water was diluted by a factor of 0.65 at station 24. Moreover, the dilution did not appear to be homogenously distributed around the Congo River mouth; similarly, satellite imagery in the Gulf of Guinea 
shows complex structures with filaments, meanders and eddies for chlorophyll distribution that mirror the surface water circulation pattern:

(http://oceancolor.gsfc.nasa.gov/SeaWiFS).

Nutrients in surface water were also influenced by the Congo inputs as shown by the nutrient-salinity relationships (Fig. 5). At salinities below 30, nutrients increased as salinity decreased, indicating that dilution by nutrient-rich fresh water was the main process controlling nutrient distributions. At salinitiy exceeding 30 , as previously observed by Van Bennekom and Berger (1984), nutrient concentrations became quite low at some stations as the result of consumption by phytoplankton: nitrate 0.05-0.1 $\mu \mathrm{mol} / \mathrm{kg}$, phosphate 0.03-0.05 $\mu \mathrm{mol} / \mathrm{kg}$ and silicate 1.3-1.5 $\mu \mathrm{mol} / \mathrm{kg}$. However, silicate displayed a transition area in water of $S=30-32$. Assuming negligible consumption and mineralisation within the estuary and permanent low concentrations in the most saline waters, extrapolating from a linear dilution provides (in absence of measurements in the Congo River itself) approximate river endmember values for nutrients of roughly $9 \mu \mathrm{mol} / \mathrm{kg}$ for nitrate, roughly $0.6 \mu \mathrm{mol} / \mathrm{kg}$ for phosphate and $195 \mu \mathrm{mol} / \mathrm{kg}$ for silicate. This value for silicate is very close to the value of $180 \mu \mathrm{mol} / \mathrm{kg}$ calculated by Van Bennekom and Berger (1984).

As observed for all biogeochemical properties, DIC was strongly related to the dilution of sea surface waters by the Congo discharge (Fig. 6). Very low DIC concentrations (minimum of $1520 \mu \mathrm{mol} / \mathrm{kg}$ ) were observed along the section at 550' S. Few DIC observations have been conducted in this region. Along a north-south transect in the Atlantic Ocean (ANT XI/1, November 1993), Bakker et al. (1999) identified the influence of the Congo discharge in the area around $5^{\circ} \mathrm{S}-8^{\circ} \mathrm{S} / 10^{\circ} \mathrm{E}$ for salinity higher than 33 (DIC data from ANT XI/1 are also shown in Fig. 6). The sea surface DIC minimum was about $1900 \mu \mathrm{mol} / \mathrm{kg}$ for ANT XI/1, much higher than concentrations detected during BIOZAIRE3. It is worth noting that in the salinity range of 33-36, the DIC data were almost identical for both cruises. This is expected as the cruises were conducted during the same period (November-December) and as increases in DIC due to anthropogenic $\mathrm{CO}_{2}$ uptake would be only about $10-15 \mu \mathrm{mol} / \mathrm{kg}$ over 10 years, more than an order of magnitude lower than DIC content $(500 \mu \mathrm{mol} / \mathrm{kg})$ observed in December 2003. The sampling strategy conducted during BIOZAIRE3 enabled us to investigate the DIC distribution at low salinities. The mixing line (DIC/S) deduced from our data led to:

$\mathrm{DIC}=46.5( \pm 1) \mathrm{SSS}+355( \pm 48)\left(R^{2}=0.969\right)$, where SSS = sea surface salinity

Because of the low salinity of the waters investigated here, this relation differs significantly from the one deduced from ANT XI/I data, i.e. DIC = 54.0 SSS + 109 (Bakker et al., 1999). In particular, the origin of the DIC/SSS relation deduced from the BIOZAIRE3 data (ca. 355 $\mu \mathrm{mol} / \mathrm{kg}$ ) is higher than the one deduced from the ANT XI/I data (ca. $109 \mu \mathrm{mol} / \mathrm{kg}$ ). Note that using only data from the open ocean, for SSS higher than 33 (as in Bakker et al., 1999), we would have obtained a significantly different regression than the one estimated from all samples:

$\mathrm{DIC}=50.6( \pm 3) \mathrm{SSS}+221( \pm 97)\left(\mathrm{R}^{2}=0.957\right)$

This suggests that the low salinity samples $(\mathrm{SSS}<30)$ are very important in the establishment of the DIC/SSS relation and interpretation of the DIC distribution in the Congo discharge area. Although our relation was deduced for salinity above 22 only, the origin that would correspond to river water DIC content $(-355 \mu \mathrm{mol} / \mathrm{kg})$ was higher than bicarbonate concentrations (200-240 $\mu \mathrm{mol} / \mathrm{kg}$ ) observed in the Congo River (Probst et al., 1992). This difference could be explained by an increase in DIC through organic matter mineralisation in the most diluted surface waters. However, net primary production occurring offshore in this area would decrease the DIC concentrations, as also suggested by the decrease in nutrients at salinity between 25 and 30 (Fig 5). This scenario and quantification of the processes that drive the DIC distribution in this area (mineralisation versus export production) should be confirmed with new observations conducted from the coast and along the river plume. 


\subsection{Deep waters}

Figures 7 and 10 show the vertical sections of oxygen and nutrients (silicate, phosphate, nitrate). In these figures, colours and isoline values were specially chosen to highlight the $4000 \mathrm{~m}$ anomaly layer and the colour scale is not linear. They were drawn using the ODV software (Schlitzer, 2008).

Figure 7 represents these parameters along the east-west section that follows the Congo channel. It shows that the oxygen anomaly started on the bottom between $7^{\circ}$ and $8 \mathrm{E}$ (Fig. $7 a)$, with the greatest decrease at stations 32,33 and 34 where the bottom values were 214 , 215 and $214 \mu \mathrm{mol} / \mathrm{kg}$ at 4123,4316 and $4475 \mathrm{dbar}$, respectively. From east to west, the oxygen concentration decreased rapidly on the bottom from $8^{\circ} \mathrm{E}$ to $7^{\circ} 30^{\prime} \mathrm{E}$ in the core of the anomaly and then increased again after $6^{\circ} \mathrm{E}$ but with a weaker gradient. West of $6^{\circ} \mathrm{E}$, the layer affected by the anomaly (thickness of $\sim 1500 \mathrm{~m}$ between the two isolines at $226 \mu \mathrm{mol} / \mathrm{kg}$ ) rose from the bottom and slowly became shallower, centred at $\sim 3700-3800 \mathrm{~m}$ at $5^{\circ} \mathrm{E}$. Thus, the oxygen content increased again on the bottom west of $6^{\circ} \mathrm{E}$. Vertical profiles of oxygen at three stations along this section (Fig. 8) illustrate the behaviour of the oxygen anomaly. At station 32, the oxygen anomaly just appears at $4000 \mathrm{~m}$ on the bottom. At station 38 , the westernmost and deepest station of the section, the oxygen anomaly was shallower and was not located on the bottom, as shown on the section (Fig. 7a). At station 36, just above the Congo lobe, a secondary deep anomaly also appeared on the bottom; its decrease was less than at station 32 and was not visible at station 38 .

On this east-west section, silicate (Fig. $7 \mathrm{~b}$ ) also increased sharply near the bottom at stations 32,33 and 34 , forming a tongue of high values $(>56 \mu \mathrm{mol} / \mathrm{kg})$ which became shallower in the deeper, western part of the section centred at $\sim 3800 \mathrm{~m}$ at $5^{\circ} \mathrm{E}$. This tongue was highly correlated with the deep oxygen anomaly. In addition, a weaker secondary anomaly of silicate appears on the bottom at station 36, which was located at the Congo lobe. The phosphate section (Fig. 7c) also showed an increase in concentrations on the bottom at stations 32, 33 and 34. A secondary bottom maximum was also observed at station 37, located above the lobe area. Above it, a tongue corresponding to a phosphate maximum (> $1.65 \mu \mathrm{mol} / \mathrm{kg}$ ) occurred shallower to the West and was centred at $\sim 3500 \mathrm{~m}$ at $5^{\circ} \mathrm{E}$. In addition to these deep anomalies, a bottom phosphate maximum was also observed at stations 28 and 27 which were located at the cold seep site Regab at $-3500 \mathrm{~m}$ and in the Congo channel near site Regab, respectively. The nitrate section (Fig. 7d) also showed a tongue of maximum values starting on the bottom at stations 32 and 33 and moving shallower to the west reaching $\sim 3800 \mathrm{~m}$ at $5^{\circ} \mathrm{E}$. No obvious secondary bottom maximum of nitrate was detectable at site Lobe. On the contrary, bottom values decreased at station 37, but increased again near the bottom at station $38\left(5^{\circ} \mathrm{E}\right)$.

Decreases in $\mathrm{pH}$ generally mimick those of oxygen due to oxidation of organic matter. However, it should be noted that significant $\mathrm{pH}$ drops were observed close to the bottom $(+15 \mathrm{~m})$ in the western part of the east-west section (Fig. 9). Compared with the average $\mathrm{pH}$ values in the water column (below $3000 \mathrm{~m}$ ), drops at stations 32 to 38 ranged from 0.08 to $0.25 \mathrm{pH}$ units, largely exceeding those measured at other locations $(0.02 \pm 0.02 \mathrm{pH}$; data not shown). Unlike the main tongues of oxygen and nutrient anomalies that rose when spreading to the western part of the east-west section, the $\mathrm{pH}$ drops remained close to the bottom.

The north-south section (Fig. 10) was set up along the $4000 \mathrm{~m}$ isobath to follow the core of the anomaly that occurs around this depth along the continental rise. Incidentally, due to the geometry of this section, the southern branch was deeper than the northern branch. Thus, the southern branch was located west of where the bottom anomaly starts to take place. On this section, it appeared that the bottom oxygen concentration (Fig. 10a) decreased more in the southern branch than in the northern branch. According to the bottom data set, two extrema were reached on each branch of this section at locations equally distant from the channel (around 180-220 km): at station 8 on the northern branch ( $4^{\circ} 30^{\prime} \mathrm{S}$ ) with $212 \mu \mathrm{mol} / \mathrm{kg}$ for oxygen and $65.3 \mu \mathrm{mol} / \mathrm{kg}$ for silicate and at station 16 on the southern branch $\left(7^{\circ} 30^{\prime} \mathrm{S}\right)$ 
with $209 \mu \mathrm{mol} / \mathrm{kg}$ for oxygen and $61.6 \mu \mathrm{mol} / \mathrm{kg}$ for silicate. These extrema did not appear clearly on the northern section plot because they were much closer to the bottom. Outside the CTD- $\mathrm{O}_{2}$ stations taken along both sections, station 20 was taken at site ZC that was part of the biological study (Fig. 1). At this location, the bottom values of $207 \mu \mathrm{mol} / \mathrm{kg}$ for oxygen and $63.3 \mu \mathrm{mol} / \mathrm{kg}$ for silicate (not shown) indicated more pronounced anomalies than at station 16 of the southern section, which was around $130 \mathrm{~km}$ away.

As observed for the east-west section, the anomaly tongue became shallower when propagating at greater depths to the west. Likewise, isolines of the southern branch were shallower because these stations were characterised by greater depths.

In addition to oxygen and nutrients (already observed by the previously cited authors), the new data on $\delta^{13} \mathrm{C}$ and DIC obtained during the BIOZAIRE3 cruise showed that mineralisation was responsible for the deep anomalies.

The variations of $\mathrm{AOU}$ and $\delta^{13} \mathrm{C}$ in the water column (Fig. 11) characterise the different water masses, with the lowest $\delta^{13} \mathrm{C}$ values and the highest $\mathrm{AOU}$ values around $400-500 \mathrm{~m}$ in the SACW and the rather homogenous NADW below $1500 \mathrm{~m}$. Anomalies of $\delta^{13} \mathrm{C}$ values recorded in the deep waters were marked by a relative decrease of $0.4 \%$ at most near $4000 \mathrm{~m}$ as compared to the overlying and underlying waters (Fig. 11) indicating that there was an additional source of ${ }^{13} \mathrm{C}$-depleted $\mathrm{CO}_{2}$ originating from the mineralisation of organic matter. The increase observed in the AOU values around the same depth seen in Fig. 11 illustrates the oxygen consumption due to this mineralisation. Isotopic mass balance calculation using $\delta^{13} \mathrm{C}$ values of $-20 \%$ or $-25 \%$ for marine organic or terrestrial matter, respectively, shows that oxidized organic carbon contributes $2 \%$ to the total DIC. Although it was not measured in the entire water column at all stations (at stations 6, 17, 28 and 31 only), DIC exhibited a well-marked slope break, at the deeper stations 6 and 17, between $3500-4000 \mathrm{~m}$ (Fig. 11). This observation is also consistent with a mineralisation process occurring at this depth. Unfortunately, no samples for DIC were taken from the entire water column at other deeper stations.

\section{Discussion}

Fresh water inputs are unbalanced in nutrients and have large excesses of silicate, relative to what phytoplankton-particularly the siliceous species such as diatoms-require. The Si/N ratio exceeded 2 and can reach 40 in productive waters $(S>30)$, much greater than the usual values for diatoms (0.5-1; from Si/C data in Van Bennekom and Berger, 1984), which are often the most abundant species. As their mean N/P ratios were about 5 and did not exceed 15 (Redfield ratio $=16$ ), the waters studied here can be considered N-limiting for phytoplankton. Using the estimation method of Van Bennekom and Berger (1984), we found $95 \%$ consumption for silicate in waters of salinity > 32 (see Fig. 5), while Van Bennekom and Berger (1984) found $90 \%$ in May and $60 \%$ in November. They also reported that primary production, expressed in carbon, exceeds $200 \mathrm{mg} \mathrm{m}^{-2} \mathrm{~d}^{-1}$ in the Congo plume. In this study, maximum primary production was found at a salinity of about $30,150-200 \mathrm{~km}$ from the river mouth.

The relations established between salinity and DIC, 180 and $13 \mathrm{C}$ values in the surface waters (Fig. 6 and 4) corresponded to mixing between two end-members: sea water from offshore Gulf of Guinea waters and fresh water from the Congo River. The Congo River endmember displays low DIC concentrations $(355 \mu \mathrm{mol} / \mathrm{kg})$, low 180 values $(-2.9 \% \mathrm{~V}-\mathrm{SMOW})$ and low $13 \mathrm{C}$ values (-2.9\% $\mathrm{V}$-PDB); these values were derived from our linear regression equations because measurements of these parameters were not available from the literature. These values do not correspond to the true Congo River values because they integrate the effects of organic matter production-regeneration as well as evaporation at the ocean's surface. 
The plot of $\delta^{13} \mathrm{C}$ and DIC values (Fig. 12) clearly shows that the surface water and water column systems were controlled by completely different processes. The surface water was dominated by the mixing with the Congo River whereas the deep water column system was essentially controlled by the mineralisation process. Maximum variations in $\delta^{13} \mathrm{C}$ and DIC with depth corresponded to a decrease in $\delta^{13} \mathrm{C}$ of $1.9 \%$ and an increase in DIC of $220 \mu \mathrm{mol} / \mathrm{kg}$; these variations indicated that the mineralisation of organic matter contributed a maximum of $9 \%$ to DIC.

As for the deep layer anomaly, the results of oxygen, nutrients, DIC and $\delta^{13} \mathrm{C}$ all point to the occurrence of mineralisation around the Congo channel. However, the data are not sufficient alone to determine whether this mineralisation occurs at the very near-bottom or by diffusion from organic-rich sediments. At site ZD, at $4000 \mathrm{~m}$ depth near the Congo Channel $(13 \mathrm{~km}$ apart), surface dry sediment contains $2 \%$ organic carbon and at site Lobe, $3.45 \%$ (Rabouille et al., this volume). From a benthic silicate balance established from BIOZAIRE3 cruise sampling, Ragueneau et al. (this volume) demonstrate that the deep silicate anomaly originates from the sediments, thereby confirming the Van Bennekom (1996) hypothesis of an upward diffusion of the silicate from the sediments.

Concerning the origin of the deep anomalies in this part of the Gulf of Guinea, our hypothesis was that they came from the particle overflows occurring at $\sim 4000 \mathrm{~m}$ depth during turbidity current events such as those observed in the Congo channel at $4000 \mathrm{~m}$ depth (Khripounoff et al., 2003) rather than from gradual downslope transport along the continental rise. The other turbidity current observed directly (by moorings) along the channel in 2004 (Vangriesheim et al, this volume) did not reach the rim of the channel valley at $\sim 3000 \mathrm{~m}$ depth, excluding a possible particle overflow. But the same turbidty event observed at $\sim 4000 \mathrm{~m}$ reached the top of the channel valley. These new observations reinforce the argument of the channel particle overflows starting not before $\sim 4000 \mathrm{~m}$ (where the anomalies appear). This is supported also by sedimentological studies that conclude that turbidity current overflow does not occur at depths shallower than $\sim 4000 \mathrm{~m}$ (Dennielou and Jouanneau, 2003). From the similarities observed during sediment studies at sites ZC and ZD (Fig. 1) of the BIOZAIRE programme, Rabouille et al. (this volume) and Ragueneau et al. (this volume) have alternative explanations. Rabouille et al. (this volume) found that "lateral input is very important since the sum of recycling and burial in the sediments is five to eight times larger than the vertical flux recorded in traps". In addition, "the magnitude of the oxygen demands on the slope is ... not correlated with the proximity of the submarine channel-levee system which indicates that cross-slope transport processes are active over the entire margin". Moreover, results of Ragueneau et al. (this volume) suggest that "the biogenic matter that degrades and dissolves in the sediments near $4000 \mathrm{~m}$ is probably not coming from the deep channel". These assertions may hold but they are debatable.

The secondary deep anomaly observed at the station 36 just above the Congo lobe visible on the oxygen profile (Fig. 8) also appeared on the silicate and phosphate sections (Fig. 7b and 7c). The lobe area corresponds to the most distal depositional area in the Congo fan, where turbidity currents end and lose the material held in suspension by turbulence. The high values of organic carbon found in the surface sediments there by Rabouille et al. (this volume) confirms the input of organic matter. We assume that the bottom anomalies at station 36 are also due to mineralisation of this particulate organic matter arriving in the lobe area, like the particulate organic matter that arrives on the bottom at stations 32, 33 and 34 .

The north-south section (Fig. 10) showed that the core of the anomaly was not centred on the channel axis but it was split into two cores on each side of the channel with noticeable symmetry (stations 8 and 16-20). This can be explained by the slightly shallower water depths at the stations near the channel. The dispersion of the particles and of the anomalies northward and southward away from the channel are promoted by highly oscillating currents at $\sim 4000 \mathrm{~m}$ (compared to a very small residual current) as shown by Vangriesheim et al. (this volume).The sediment studies at sites ZD and ZC (Rabouille et al., this volume) and the 
fauna observations of (Galéron et al., this volume) suggest that mineralisation in the sediments occurs at these both sites at magnitudes of the same order. They explain this similitude by a negligible influence of the channel inputs. If the sediment processes seem not so influenced by the channel input at these two stations, it could indicate that the anomalies do not come only from sediment processes as asserted by Ragueneau et al., (this volume) but also from water column mineralization processes shown by the $\mathrm{AOU}, \delta^{13} \mathrm{C}$ and DIC results at this water depth.

Moreover, a downslope transport origin does not explain why the anomalies start only around $4000 \mathrm{~m}$ depth. Downslope transport from the shelf would probably result in mineralisation at depths shallower than $4000 \mathrm{~m}$ only. In the BIOZAIRE area, the fact that the deep anomalies never appeared shallower than ca. $4000 \mathrm{~m}$ is a major reason for which downslope transport along the rise alone is insufficient to explain the deep anomalies. In addition, long-term current measurements did not show down-slope currents (Vangriesheim et al., this volume). Nevertheless, although overflow above the channel is probably the main cause of the deep anomalies in the Congo channel area, the anomalies also found at ca. $4000 \mathrm{~m}$, but at some distance from the Congo channel (Warren and Speer, 1991), (Arhan et al., 1998), (Braga et al., 2004) are probably due to another process (or several) at the scale of the Gulf of Guinea which still have to be explained.

Another result to point out concerns the near-bottom $\mathrm{pH}$ decrease in the western part of the east-west section (Fig. 9). pH drops were much greater than the expected values of reproducibility in the overlying water column, suggesting that they were not analytical artefacts. These $\mathrm{pH}$ anomalies cannot be attributed to a particular water mass (for instance the bottom water) since their magnitude is too great and not depth-dependent. Since Ternon et al. (2001) did not mention any similar drop at a latitude slightly north (4 $\left.4^{\circ} 30^{\prime} \mathrm{S}\right)$, these $\mathrm{pH}$ drops therefore seem to be only located at the end of the Congo channel. Maximum effects were indeed observed at lobe area stations 36 and 37 . This $\mathrm{pH}$ anomaly was close to the bottom on the western branch, whereas the oxygen and nutrient anomaly tongue formed at $4000 \mathrm{~m}$ rose above the bottom at these stations. The process responsible for such anomalies has thus not been identified, but if it originates from carbon dioxide production, it could result from aerobic or anaerobic oxidation of organic matter in superficial sediments that differ slightly from those at $4000 \mathrm{~m}$. Quantitatively, 0.08 to $0.25 \mathrm{pH}$ drops require an additional 30 to $100 \mu \mathrm{mol} / \mathrm{kg} \mathrm{CO}$, i.e. 1.5 to $5 \%$ of total DIC, (DIC was unfortunately not measured at deeper stations). The difference in behaviour of the different parameters suggests that the processes occurring at site Lobe were not exactly the same as those at $4000 \mathrm{~m}$.

\section{Conclusions}

The physical and chemical measurements performed in the water column of the Gulf of Guinea during the BIOZAIRE3 cruise in the Congo deep-sea fan helped detail the influence of the Congo River inputs in the surface layer as well as in the deep layer where it may induce novel conditions for benthic fauna living on/in the sediments at $4000 \mathrm{~m}$ and deeper.

In the surface layer, within the Congo surface plume, nutrients, DIC and stable isotopes of oxygen and carbon were used together for the first time to provide a view of primary production and organic matter mineralisation. Deviation in concentrations from pure physical dilutions was marked in the most saline end-member, while less altered relationships in turbid, low saline waters (down to a salinity of 23) facilitated the estimation of river water concentrations by extrapolation. Nutrient ratios suggested that nitrogen was limiting for phytoplankton growth in the Congo plume.

In the deep layer, oxygen (decrease) and nutrients (increase) anomalies previously observed at ca. $4000 \mathrm{~m}$ and deeper were described in more detail to determine if they originate from Congo channel overflows associated with turbidity currents at $\sim 4000 \mathrm{~m}$. Additional parameters were measured: DIC, stable isotopes of oxygen and carbon, $\mathrm{pH}$. They all 
confirmed that the anomalies were due to mineralisation of particulate organic matter. From the two CTD-O ${ }_{2}$ sections, we deduced that they originated on the bottom at $4000 \mathrm{~m}$ depth and spread north and south along this isobath following the bottom, whilst they became gradually shallower when spreading to the west at greater water depths.

From the westernmost CTD-O ${ }_{2}$ stations, a second source of such anomalies also appeared just on the Congo lobe, but at lower magnitude, also associated with the large particle input from the Congo channel. In this area, a significant decrease in $\mathrm{pH}$ at the bottom was observed. Attributed to different oxidation process, it could not be directly linked to the first anomaly tongue which was shallower at these depths.

From the north-south CTD-O ${ }_{2}$ section, it seems that the core of the $4000 \mathrm{~m}$ anomalies was not located just on the Congo channel but was separated into two cores that appeared to be symmetrically distributed on each side of the channel (180-220 km apart). This distribution could be explained by the difficulty of designing $\mathrm{CTD}-\mathrm{O}_{2}$ sections that follow the cores exactly: the CTD-O ${ }_{2}$ stations close to the channel are slightly shallower than the anomaly core and the southern section is deeper than the northern one. However, it does not exclude a Congo channel overflow origin, as suggest the results by Ragueneau et al. (this volume) and Rabouille et al. (this volume). They suggest that it is mainly due to the downslope particle transport. A downslope particle input may also occurs along the Gulf of Guinea margin, but it does not explain why anomalies appear only at $4000 \mathrm{~m}$ depth. In the BIOZAIRE area, the Congo channel overflow due to turbidity currents probably plays a major role in the $4000 \mathrm{~m}$ anomaly formation.

\section{Acknowledgments}

We would like to thank Myriam Sibuet, head of the BIOZAIRE project, Alexis Khripounoff, chef scientist of the BIOZAIRE3 cruise and Bernard Bourlès (IRD) for his collaboration. Thanks also to the crew of the RV L'Atalante, to Claudie Marec for lending the CNRS/INSU CTD-O ${ }_{2}$, to Jean-Pierre Gouillou, Pierre Brannellec and Rémy Chuchla for their help in calibrating the CTD, to Marie José Urrutiaguer for stable isotope measurements and to the Service SNAPO-CO2 (LOCEAN/ISPL) for DIC analysis. These studies were partly funded by the Total oil company. 


\section{References}

Aminot, A., Kérouel, R., 2004. Hydrologie des écosystèmes marins. Paramètres et analyses. Editions Ifremer, Plouzané.

Arhan, M., Mercier, H., Bourlès, B., Gouriou, Y., 1998. Hydrographic sections across the Atlantic at $7^{\circ} 30 \mathrm{~N}$ and $4^{\circ} 30 \mathrm{~S}$. Deep-Sea Research I 45, 829-872.

Babonneau, N., Savoye, B., Cremer, M., Klein, B., 2002. Morphology and architecture of the present channel system of Zaire Deep-Sea Fan. Marine and Petroleum Geology 19 (4), 445467.

Bakker, D.C.E., de Baar, H.J.W., de Jong, E., 1999. The dependence on temperature and salinity of dissolved inorganic carbon in East Atlantic Surface waters. Marine Chemistry 65, 263-280.

Benson, B.B., Krause, D., Jr., 1984. The Concentration and Isotopic Fractionation of Oxygen Dissolved in Freshwater and Seawater in Equilibrium with the Atmosphere. Limnology and Oceanography 29 (3), 620-632.

Braga, E.S., Andrie, C., Bourles, B., Vangriesheim, A., Baurand, F., Chuchla, R., 2004. Congo River signature and deep circulation in the eastern Guinea Basin. Deep Sea Research Part I: Oceanographic Research Papers 51 (8), 1057-1073.

Corbière, A., Metzl, N., Reverdin, G., Brunet, C., Takahashi, T., 2007. Interannual and decadal variability of the oceanic carbon in the North Atlantic subpolar gyre. Tellus B 59 (2), 168-179.

Craig, H., 1957. Isotopic standards for carbon and oxygen and correction factors for mass spectrometric analysis of carbon dioxide. Geochimica et Cosmochimica Acta 12, 133-149.

Craig, H., 1961. Standards for reporting concentration of deuterium and oxygen 18 in natural waters. Science 133, 1833-1834.

Craig H. and Gordon L.I., 1965. Deuterium and oxygen 18 variations in the Ocean and the Marine Atmosphere.In: Stable Isotopes in Oceanographic Studies. and Paleotemperatures (Spoleto, Italy), Editor : Tongiorgi E., CNR, pp. 9-130.

Dennielou, B., Jouanneau, J.-M., 2003. Age control on the Zaire (Congo) deep-sea fan: from $100 \mathrm{ka}$ to decadal scale., American Association of Petroleum Geologists Annual Meeting Program (abstract), 40pp.

DOE, 1994. Handbook of methods for the analysis of the various parameters of the carbon dioxide system in sea water.

Edmond, J.M., 1970. High precision determination of titration alkalinity and total carbon dioxide content of sea water by potentiometric titration. Deep-Sea Research 17, 737-750.

Eisma, D., Van Bennekom, A.J., 1978. The Zaire river and estuary and the Zaire outflow in the Atlantic Ocean. Netherlands Journal of Sea Research 12 (3/4), 255-272.

Epstein, S., Mayeda, T.K., 1953. Variations of the $180 / 160$ ratio in natural waters. Geochimica et Cosmochimica Acta 4, 212-224.

Galéron, J., Menot, L., Renaud, N., Crassous, P., Khripounoff, A., Treignier, C., Sibuet, M., this volume. Spatial and temporal patterns of benthic macrofaunal communities on the deep continental margin in the Gulf of Guinea. Deep Sea Research II.

Khripounoff, A., Vangriesheim, A., Babonneau, N., Crassous, P., Denniellou, B., Savoye, B., 2003. Direct observation of intense turbidity activity in the Zaire submarine valley at $4000 \mathrm{~m}$ water depth. Marine Geology (194), 151-158.

Kroopnick, P., 1974. The dissolved $\mathrm{O}_{2}-\mathrm{CO} 2-{ }^{13} \mathrm{C}$ system in the Eastern Eaquatorial Pacific. Deep-Sea Research 32 (1), 57-84.

Millero, F., Lee, K., Roche, M., 1998. Distribution of alkalinity in the surface waters of the major oceans. Marine Chemistry 60, 111-130.

Oudot, C., Morin, P., Baurand, F., Wafar, M., Le Corre, P., 1998. Northern and southern water masses in the equatorial Atlantic : distribution of nutrients on the WOCE A6 and A7 lines. Deep-Sea Research I 45, 873-902.

Pierre, C., Vergnaud-Grazzini, C., Faugeres, J.C., 1991. Oxygen and carbon stable isotope tracers of the water masses in the Central Brazil Basin. Deep-Sea Research 38 (5), 597-606. 
Probst, J.-L., Nkounkou, R., Krempp, G., Bricquet, J.-P., Thiébaud, J.-P., Olivry, J.-C., 1992. Dissolved major elements exported by the Congo and the Ubangi rivers during the period 1987-1989. Journal of Hyrology 135, 237-257.

Rabouille, C., Caprais, J.C., Lansard, B., Crassous, P., Dedieu, K., Reyss, J.-L., Khripounoff, A., this volume. Organic matter budget in the Southeast Atlantic continental margin close to the Congo Canyon: In situ measurements of sediment oxygen consumption.

Ragueneau, O., Regaudie-de-Gioux, A., B. Moriceau, A., Gallinari, M., Vangriesheim, A., Baurand, F., Khripounoff, A., this volume. A benthic Si mass balance on the Congo margin: origin of the 4,000 m DSi anomaly and implications for the transfer of Si from land to ocean.

Savoye, B., Cochonat, P., Apprioual, R., Bain, O., Baltzer, A., Bellec, V., Beuzart, P., Bourillet, J.F., Cagna, R., Cremer, M., Crusson, A., Dennielou, B., Diebler, D., Droz, L., Ennes, J.C., Floch, G., Guiomar, M., Harmegnies, F., Kerbrat, R., Klein, B., Kuhn, H., Landuré, J.Y., Lasnier, C., Le Drezen, E., Le Formal, J.P., Lopez, M., Loubrieu, B., Marsset, T., Migeon, S., Norland, A., Nouzé, H., Ondréas, H., Pelleau, P., Saget, P., Séranne, M., Sibuet, J.C., Tofani, R., Voisset, M., 2000. Structure et évolution récente de l'éventail turbiditique du Zaïre : premiers résultats scientifiques des missions d'exploration ZaïAngo 1 \& 2 (marge congo-angola). Comptes-Rendus de l'Académie des Sciences de Paris, Sciences de la Terre et des Planète 331, 211-220.

Savoye, B., Denniellou, B., Babonneau, N., Bez, M., this volume. Introduction to the AngolaCongo Margin, the Congo deep-sea fan and its submarine valleys.

Schlitzer, R., 2008. Ocean Data View. http://odv.awi.de.

Sibuet, M., Vangriesheim, A., Galeron, J., Menot, L., Olu, K., Khripounof, A., Fabri, M.C., Savoye, B., Caprais, J.C., Crassous, P., Miné, J., PARTICIPANTS, A.O.C., this volume. The project BIOZAIRE. Deep Sea Research Part II.

Stramma, L., England, M., 1999. On the water masses and mean circulation of the South Atlantic Ocean. Journal of Geophysical Research Oceans 104 (C9), 20863-20883.

Ternon, J.F., Oudot, C., Gourlaouen, V., Diverres, D., 2001. The determination of pHT in the equatorial Atlantic Ocean and its role in the sound absorption modeling in seawater. Journal of Marine Systems 30 (1-2), 67-87.

Van Bennekom, A.J., 1996. Silica signals in the South Atlantic. In: Wefer, G., Berger, W.H., Webb, D.J. (Eds.), The South Atlantic: Present and Past Circulation. Springer-Verlag, Berlin, pp. 345-354.

Van Bennekom, A.J., Berger, G.W., 1984. Hydrography and silica budget of the Angola Basin. Netherlands Journal of Sea Research 17 (2-4), 149-200.

Vangriesheim, A., Khripounoff, A., Crassous, P., this volume. Turbidity events observed in situ along the Congo deep-sea channel.

Warren, B.A., Speer, K.G., 1991. Deep circulation in the eastern South Atlantic ocean. DeepSea Research 38 (1), 281-322. 
Tables

Table 1

Date, time, locations and water depths $(\mathrm{m})$ at the $\mathrm{CTD}-\mathrm{O}_{2}$ stations performed during the Biozaire3 cruise with indication where samples were taken for isotopic analysis and DIC measurements (S: Surface water. X: Water column).

\begin{tabular}{|c|c|c|c|c|c|c|c|}
\hline $\mathrm{NO}$ & DATE & HEURE & LATITUDE & LONGITUDE & DEPTH & Isotopes & $\mathrm{DIC}$ \\
\hline 1 & $14 / 12 / 03$ & 07:09:44 & S 0244.915 & E 060.0041 & 4138 & & \\
\hline 2 & $14 / 12 / 03$ & $11: 10: 27$ & S 0244.931 & E 060.0000 & 4137 & S & $\mathrm{S}$ \\
\hline 3 & $14 / 12 / 03$ & 17:48:35 & S 0257.002 & E 0630.0127 & 4171 & $\mathrm{~S}$ & $S$ \\
\hline 4 & $15 / 12 / 03$ & $00: 57: 39$ & S 038.4267 & E 0659.9959 & 4197 & $\mathrm{~S}$ & $\mathrm{~S}$ \\
\hline 5 & $15 / 12 / 03$ & $08: 32: 32$ & S 0320.982 & E 0730.0221 & 4171 & $S$ & $S$ \\
\hline 6 & $15 / 12 / 03$ & 14:58:55 & S 0329.966 & E 080.0163 & 4166 & $\mathrm{X}$ & $X$ \\
\hline 7 & $15 / 12 / 03$ & $21: 39: 08$ & S 040.0545 & E 0759.9561 & 4082 & $\mathrm{~S}$ & $\mathrm{~S}$ \\
\hline 8 & $16 / 12 / 03$ & 03:53:36 & S 0429.994 & E 0759.9761 & 4112 & $S$ & $S$ \\
\hline 9 & $16 / 12 / 03$ & 10:46:11 & S 050.0386 & E 0759.9848 & 4102 & $X$ & $S$ \\
\hline 10 & $16 / 12 / 03$ & $17: 06: 35$ & S 0530.009 & E 0759.9873 & 4109 & $S$ & S \\
\hline 11 & $17 / 12 / 03$ & $01: 45: 45$ & S 0550.801 & E 0820.4727 & 3971 & $S$ & $S$ \\
\hline 12 & $17 / 12 / 03$ & $12: 43: 01$ & S 0542.673 & E 0826.0752 & 3944 & $S$ & $S$ \\
\hline 13 & $20 / 12 / 03$ & $20: 34: 30$ & S 060.0085 & E 0759.9975 & 4106 & $\mathrm{~S}$ & $\mathrm{~S}$ \\
\hline 14 & $21 / 12 / 03$ & $03: 12: 46$ & S 0630.037 & E 0816.7794 & 4062 & $X$ & $\mathrm{~S}$ \\
\hline 15 & $21 / 12 / 03$ & 10:25:07 & S 070.0134 & E 0834.1856 & 4185 & $S$ & $S$ \\
\hline 16 & $21 / 12 / 03$ & $17: 17: 03$ & S 0730.005 & E 0851.006 & 4181 & $S$ & $S$ \\
\hline 17 & $22 / 12 / 03$ & $00: 25: 00$ & S 0800.006 & E 098.405 & 4261 & $X$ & $X$ \\
\hline 18 & $22 / 12 / 03$ & 06:55:00 & S 0830.035 & E 0925.780 & 4342 & $S$ & $S$ \\
\hline 19 & $22 / 12 / 03$ & $13: 45: 56$ & S 0900.013 & E 0942.602 & 4247 & $\mathrm{~S}$ & \\
\hline 20 & 23/12/03 & 01:06:43 & S 0739.913 & E 100.3961 & 3994 & X & $\mathrm{S}$ \\
\hline 21 & $25 / 12 / 03$ & 06:39:45 & S 0720.804 & E 1129.9708 & 1302 & $X$ & S \\
\hline 22 & $26 / 12 / 03$ & $18: 49: 40$ & S 0549.992 & E 1129.9555 & 229 & S & \\
\hline 23 & $26 / 12 / 03$ & $21: 53: 34$ & S 0550.006 & E 1114.9593 & 1124 & $X$ & $X$ \\
\hline 24 & $27 / 12 / 03$ & $01: 42: 33$ & S 0550.009 & E 1059.9987 & 2045 & $S$ & \\
\hline 25 & $27 / 12 / 03$ & $06: 19: 04$ & S 0550.020 & E 1029.9831 & 2065 & $\mathrm{X}$ & $X$ \\
\hline 26 & $27 / 12 / 03$ & $11: 40: 05$ & S 0549.990 & E 0959.9936 & 2959 & $S$ & $S$ \\
\hline 27 & 29/12/03 & $06: 12: 19$ & S 0551.131 & E 0940.0039 & 3434 & $S$ & $S$ \\
\hline 28 & $30 / 12 / 03$ & 04:11:43 & S 0547.867 & E 0942.6650 & 3160 & $X$ & $X$ \\
\hline 29 & 04/01/04 & $12: 48: 33$ & S 0549.975 & E 0929.9799 & 3329 & $X$ & \\
\hline 30 & 04/01/04 & $18: 14: 48$ & S 0549.957 & E 090.0059 & 3692 & $S$ & $X$ \\
\hline 31 & 05/01/04 & $02: 52: 54$ & S 0549.971 & E 0830.0259 & 3880 & $X$ & $X$ \\
\hline 32 & 05/01/04 & $17: 18: 13$ & S 0550.034 & E 0759.9901 & 4087 & $X$ & $S$ \\
\hline 33 & 06/01/04 & 00:17:09 & S 0550.013 & E 0729.9929 & 4271 & $S$ & S \\
\hline 34 & $06 / 01 / 04$ & 06:25:08 & S 0550.001 & E 0659.9681 & 4430 & $X$ & $S$ \\
\hline 35 & $06 / 01 / 04$ & 13:29:52 & S 0610.008 & E 0630.0077 & 4600 & $S$ & $S$ \\
\hline 36 & $07 / 01 / 04$ & $00: 44: 33$ & S 0628.318 & E 061.6799 & 4790 & $X$ & S \\
\hline 37 & $07 / 01 / 04$ & $10: 45: 39$ & S 0648.977 & E 0530.0049 & 4948 & $S$ & S \\
\hline 38 & $07 / 01 / 04$ & $17: 52: 48$ & S 078.0187 & E 050.0113 & 5025 & $\mathrm{X}$ & S \\
\hline
\end{tabular}

\section{Figures}




\section{Figure 1}

Bathymetric map of the area studied during the BIOZAIRE programme in the Gulf of Guinea (rectangle in the inset map) with locations of the CTD-O ${ }_{2}$ stations (numbered from 1 to 38) performed during the BIOZAIRE3 cruise (December 2003- January 2004). Isobath depths are given in meters. The rectangles are areas that were intensively studied in the BIOZAIRE programme.

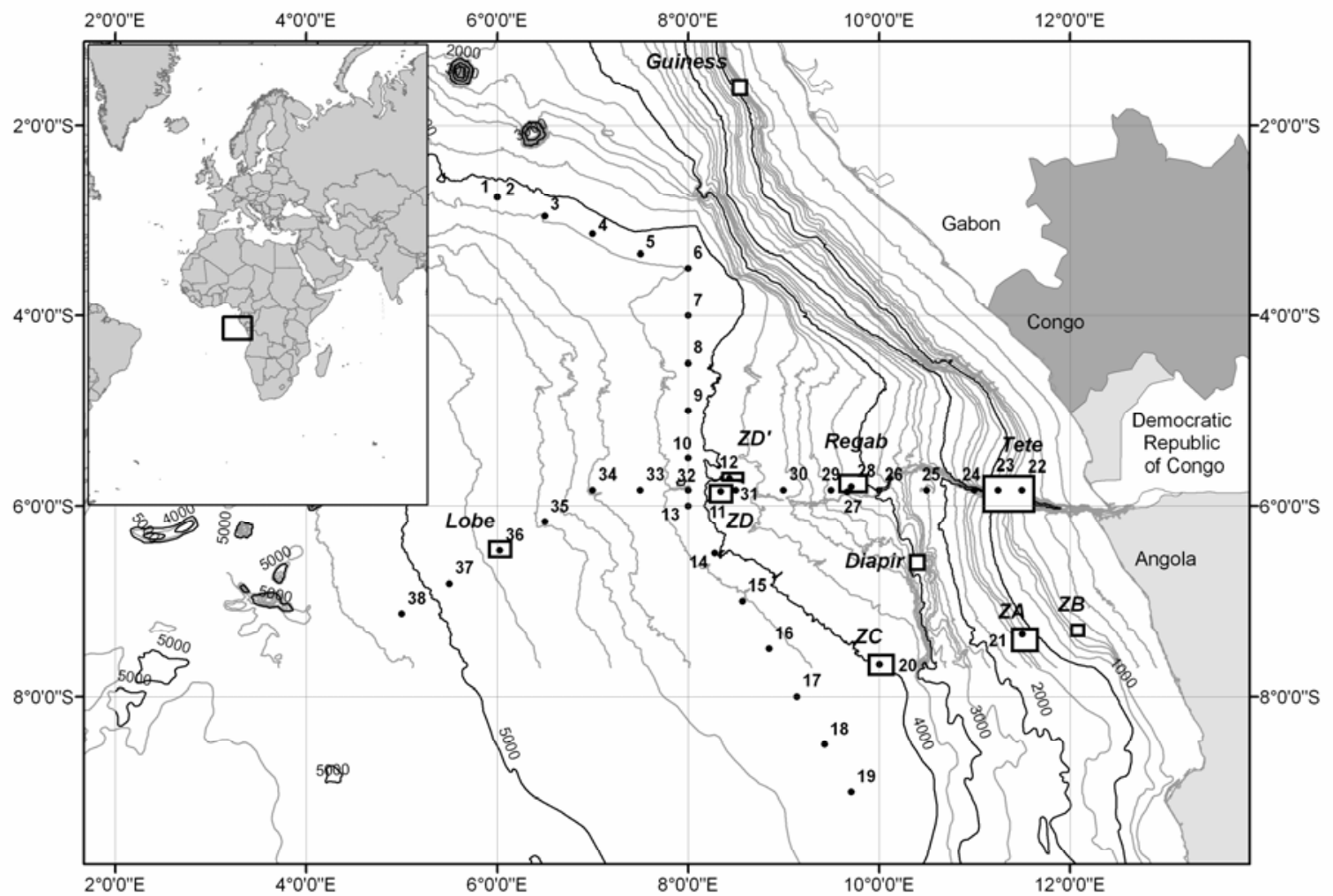


Figure 2

Two sections of turbidity profiles obtained during the Equalant 2000 cruise with a LSS (Light Back Scattering Sensor, WET Labs, USA). The sections were performed along $6^{\circ} \mathrm{E}$ longitude from the North (CTD 68 to 76 ) and along $6^{\circ} \mathrm{S}$ latitude, i.e. near the channel axis (CTD 76 to 85) and then toward Pointe Noire (CTD 86 to 89) as shown in the inset map (Braga et al., 2004). For each section, the x-axis (Volts) corresponds to the leftmost profile, the other profiles being offset by 0.02 from each other for readability. The near-bottom signal increase is due to higher particle concentration in the so-called bottom nepheloid layer.

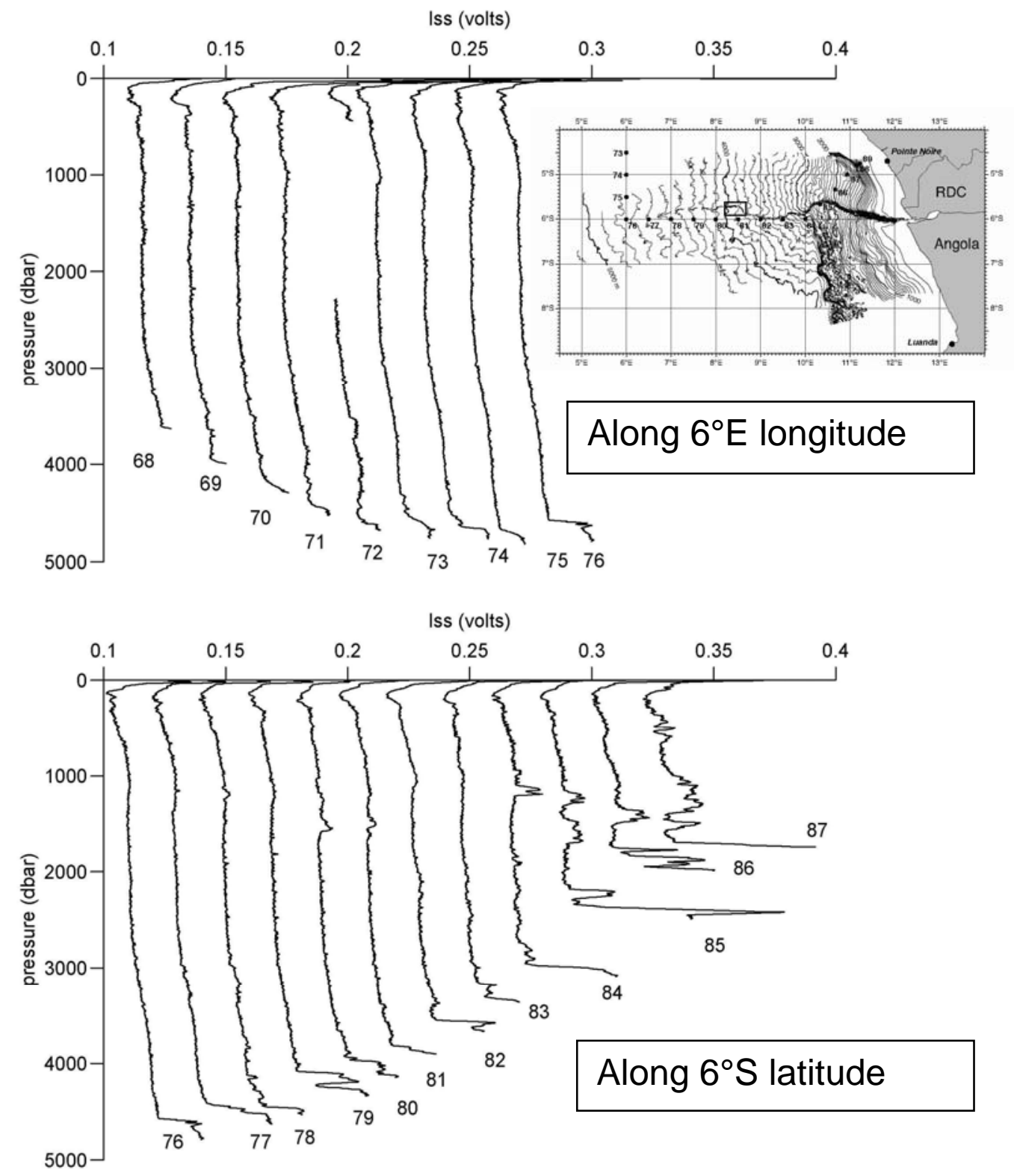


Figure 3 :

Left: Relation between AOU (Apparent Oxygen Utilisation = oxygen concentration at saturation minus measured oxygen) and salinity in surface water in the Gulf of Guinea along the BIOZAIRE3 CTD sections.

Right: Longitudinal distribution of AOU (Apparent Oxygen Utilisation = oxygen concentration at saturation minus measured oxygen) in surface water in the Gulf of Guinea along the BIOZAIRE3 CTD sections.

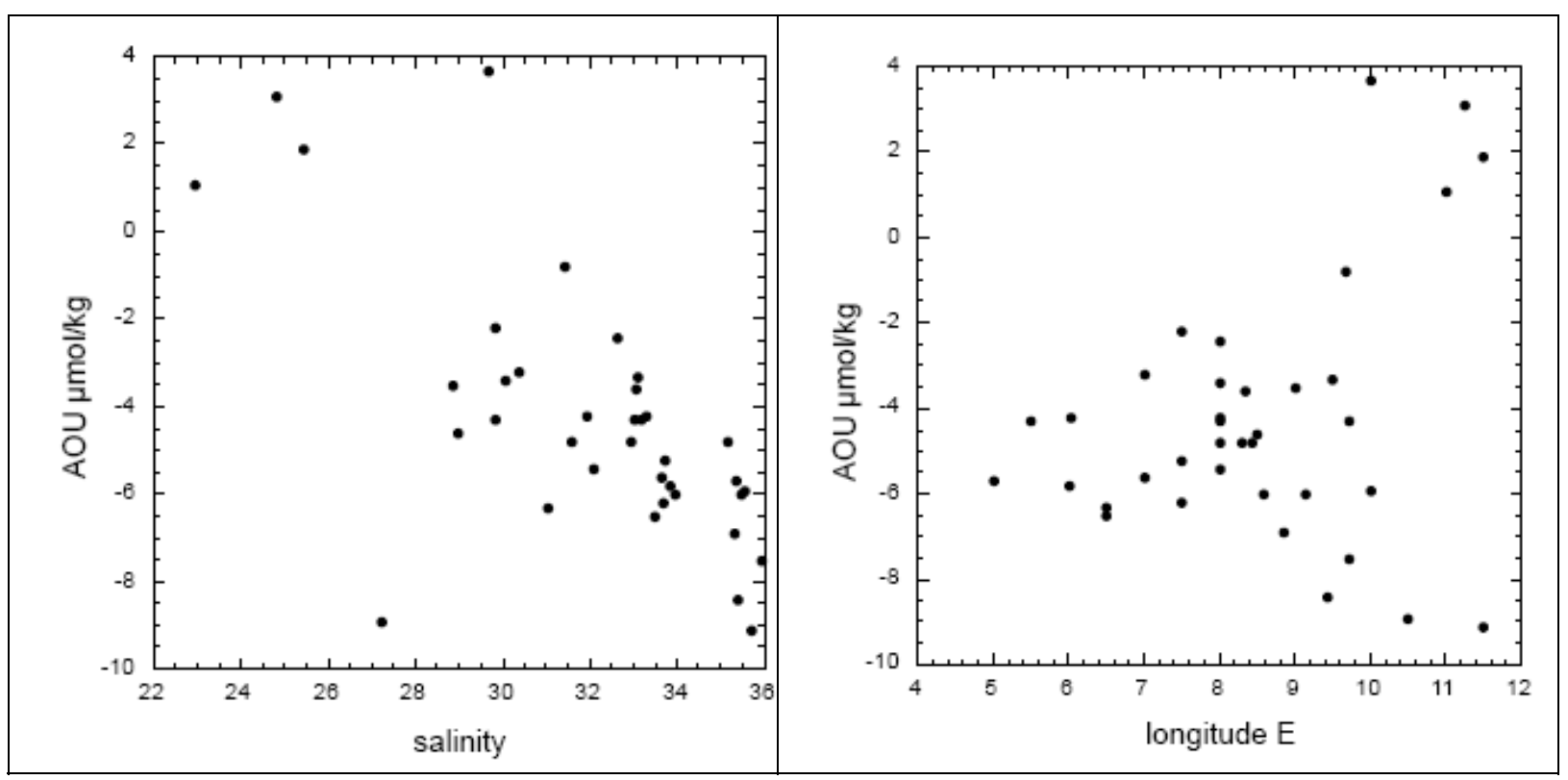


Figure 4 :

Left: Relationship between $\delta^{18} \mathrm{O}$ values of water and salinity in surface water in the Gulf of Guinea along the BIOZAIRE3 sections.

Right: Relationship between $\delta^{13} \mathrm{C}$ values of DIC and salinity in surface water in the Gulf of Guinea along the BIOZAIRE3 sections.

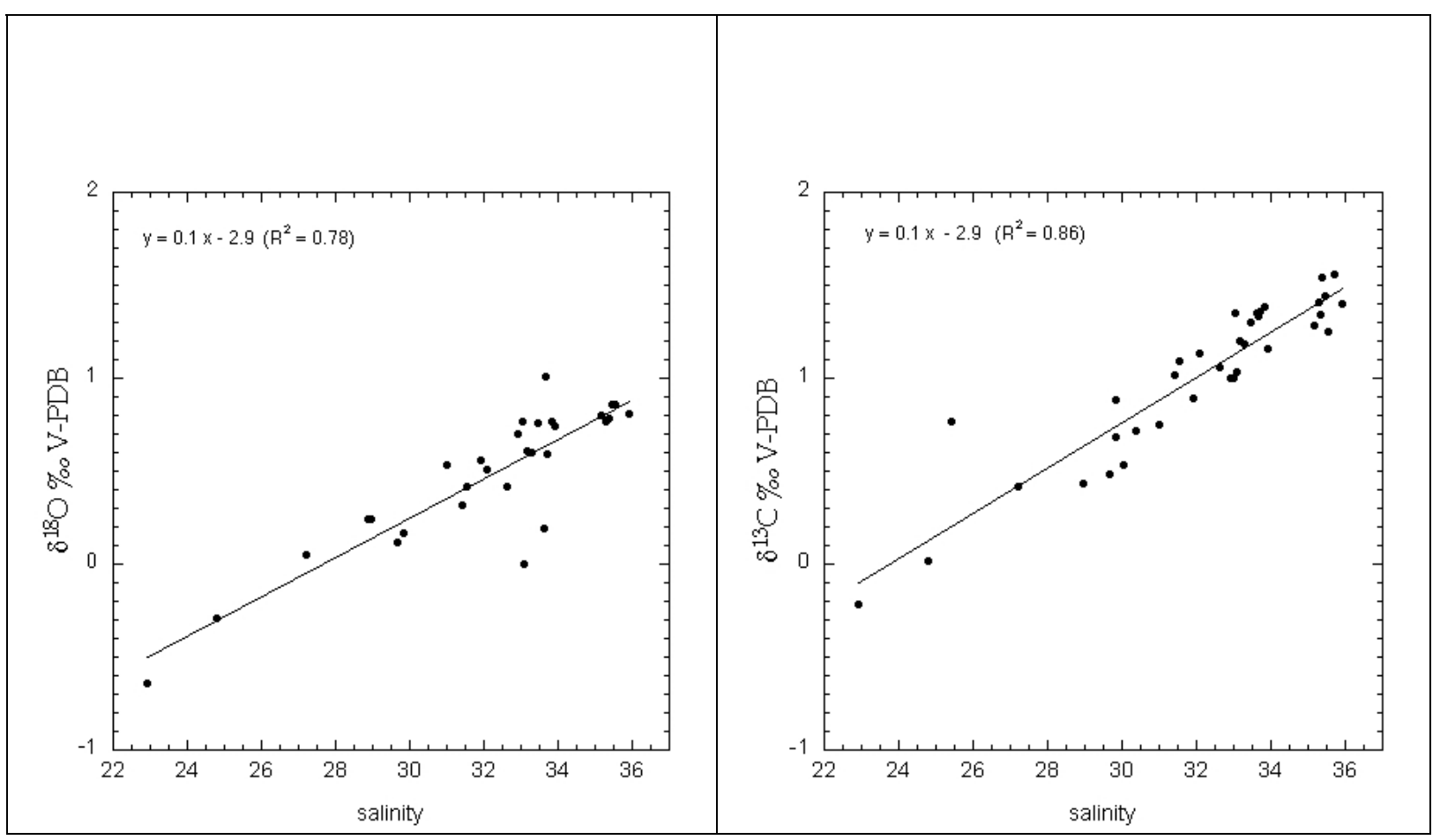




\section{Figure 5}

Nutrient-salinity relationships in surface waters in the BIOZAIRE area; (a) nitrate, (b) phosphate, (c) silicate. Approximate theoretical dilution lines are shown (see text). For silicate, the relationship in depleted waters greater than $S=32$ is indicated.
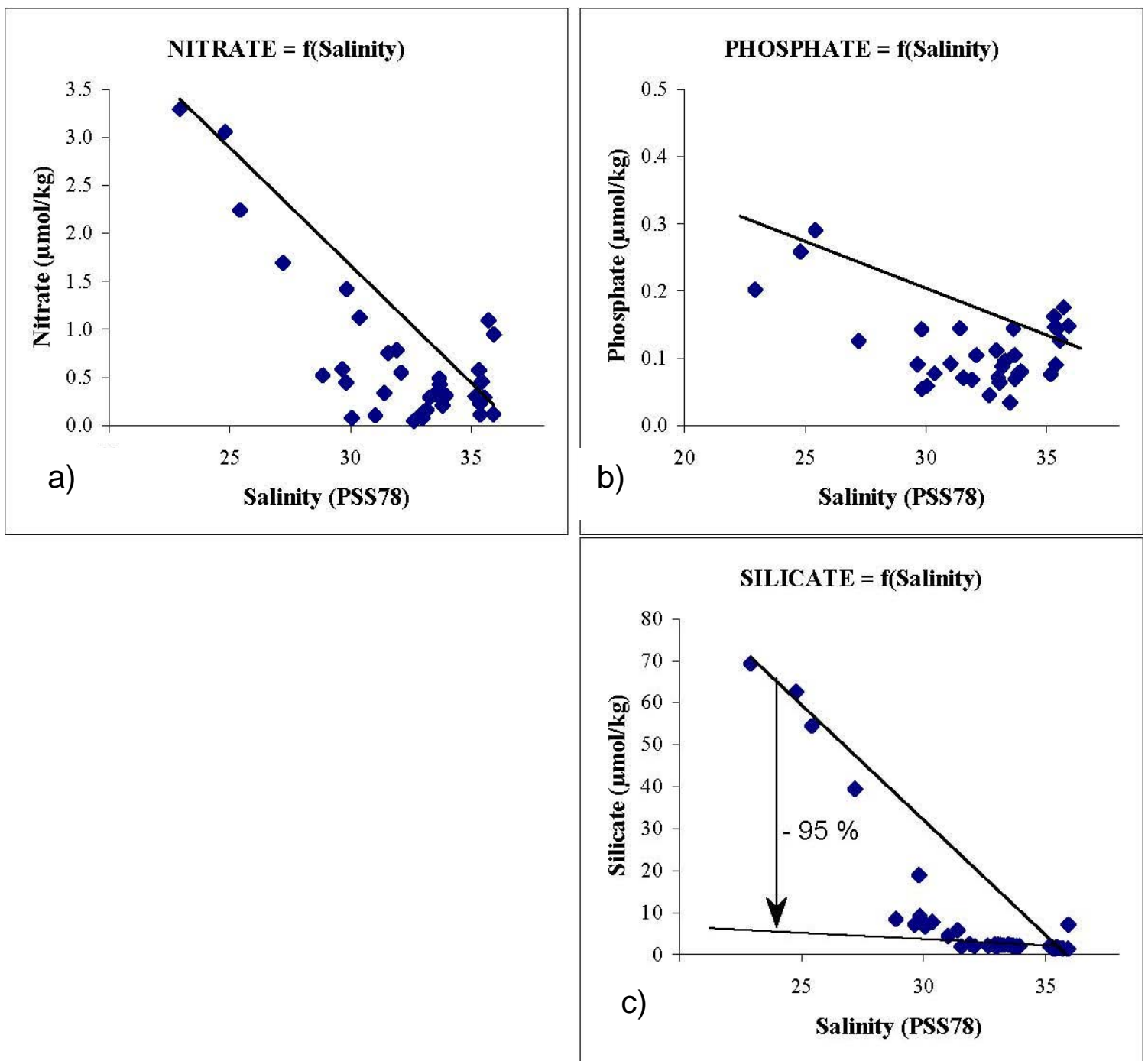


\section{Figure 6}

Surface water DIC concentrations ( $\mu \mathrm{mol} / \mathrm{kg}$ ) with respect to salinity observed in the Congo discharge area during the BIOZAIRE3 cruise (December 2003 - January 2004, large circles) and the ANT XI/1 cruise (November 1993, grey symbols, Bakker et al., 1999). The dashed line indicates the linear regression using BIOZAIRE3 observations.

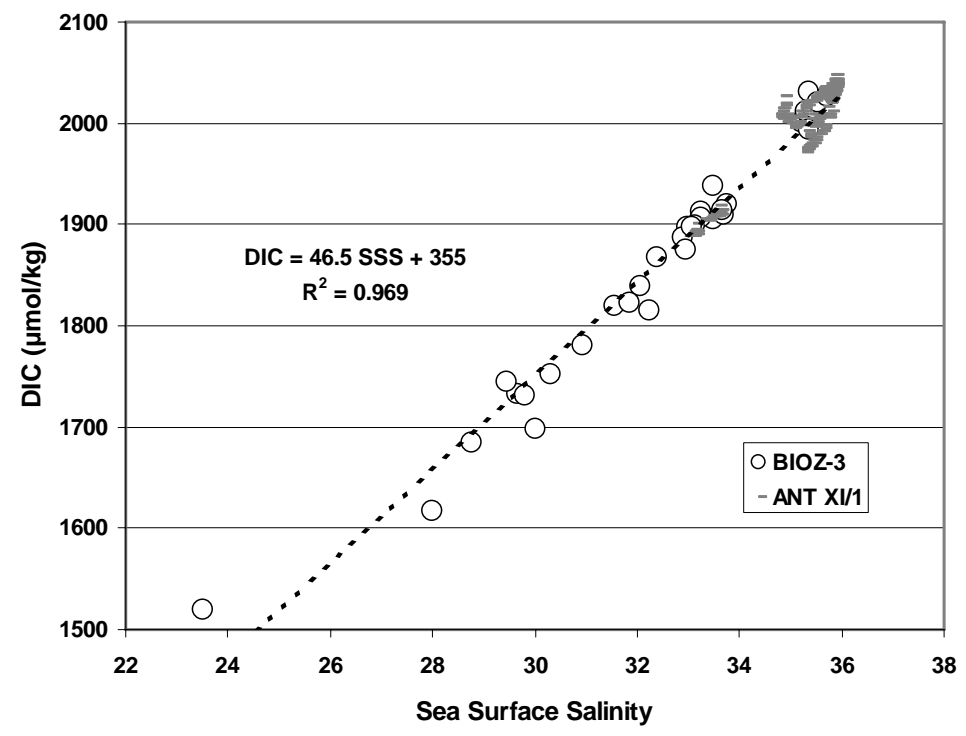


Figure 7

Oxygen and nutrient distribution on the east-west section above the Congo channel axis (west on the left). The colour scale, chosen to highlight the deep layer anomaly, is not linear Temperature and salinity vertical profiles are given below (a).

(a) Oxygen. (b) Silicate. (c) Phosphate. (d) Nitrate.

Drawn with ODV software Schlitzer, R., 2008 http://odv.awi.de.
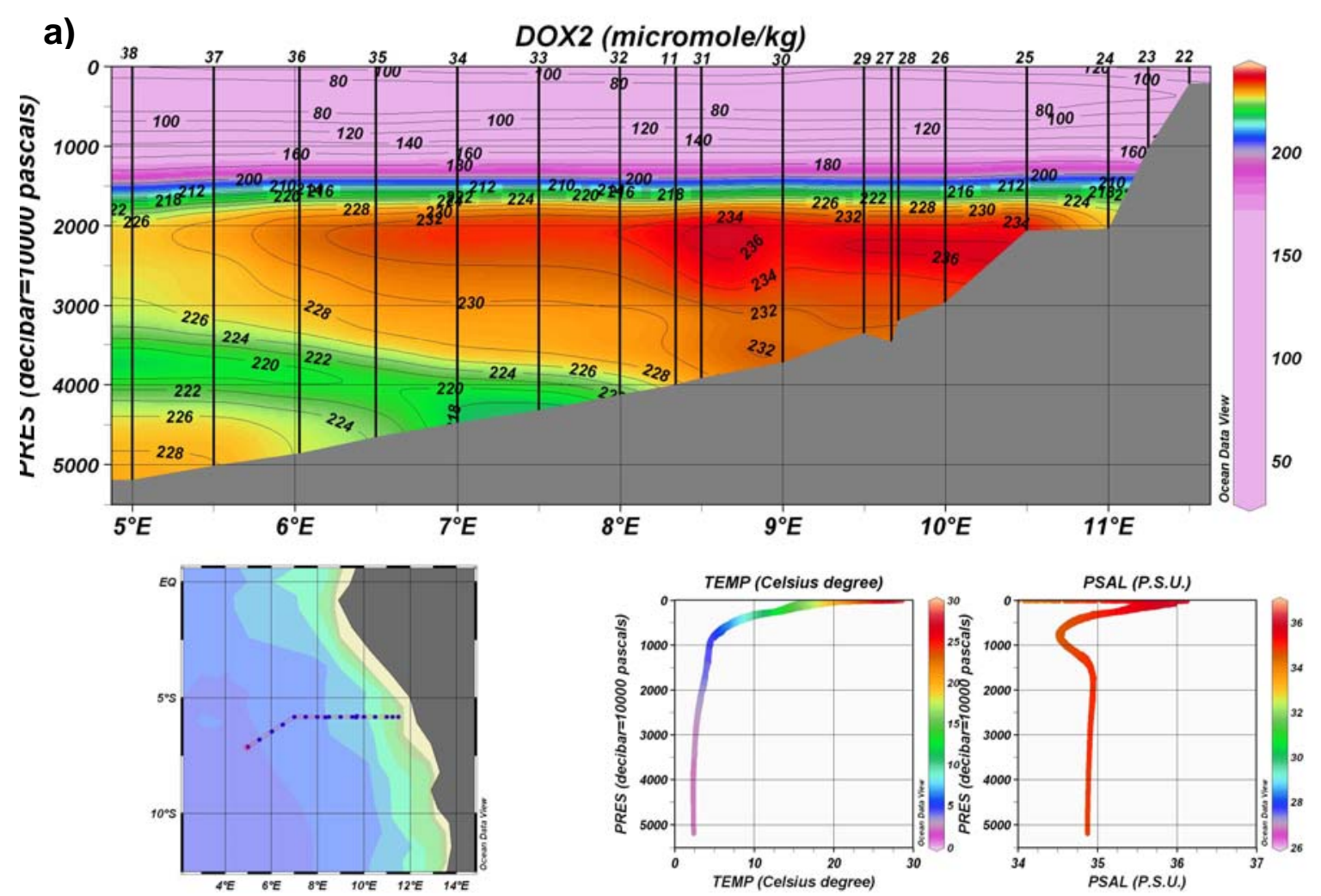


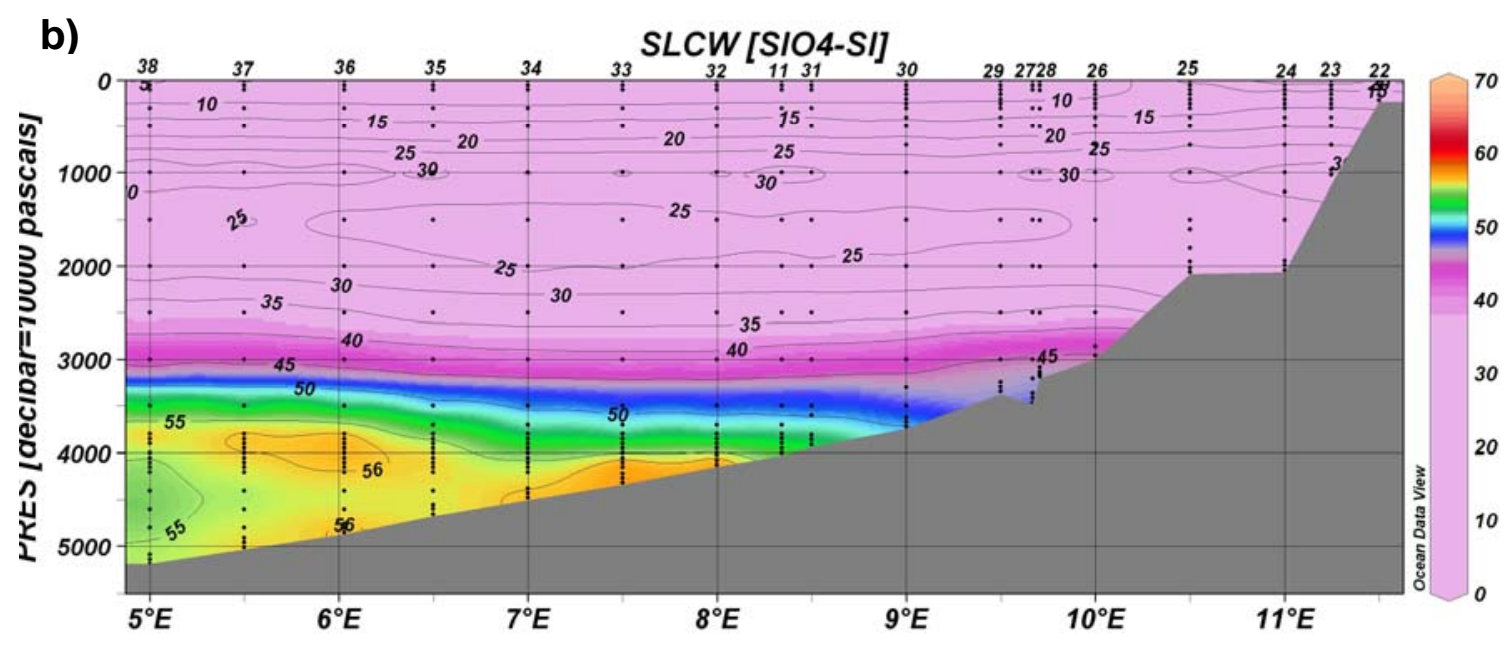




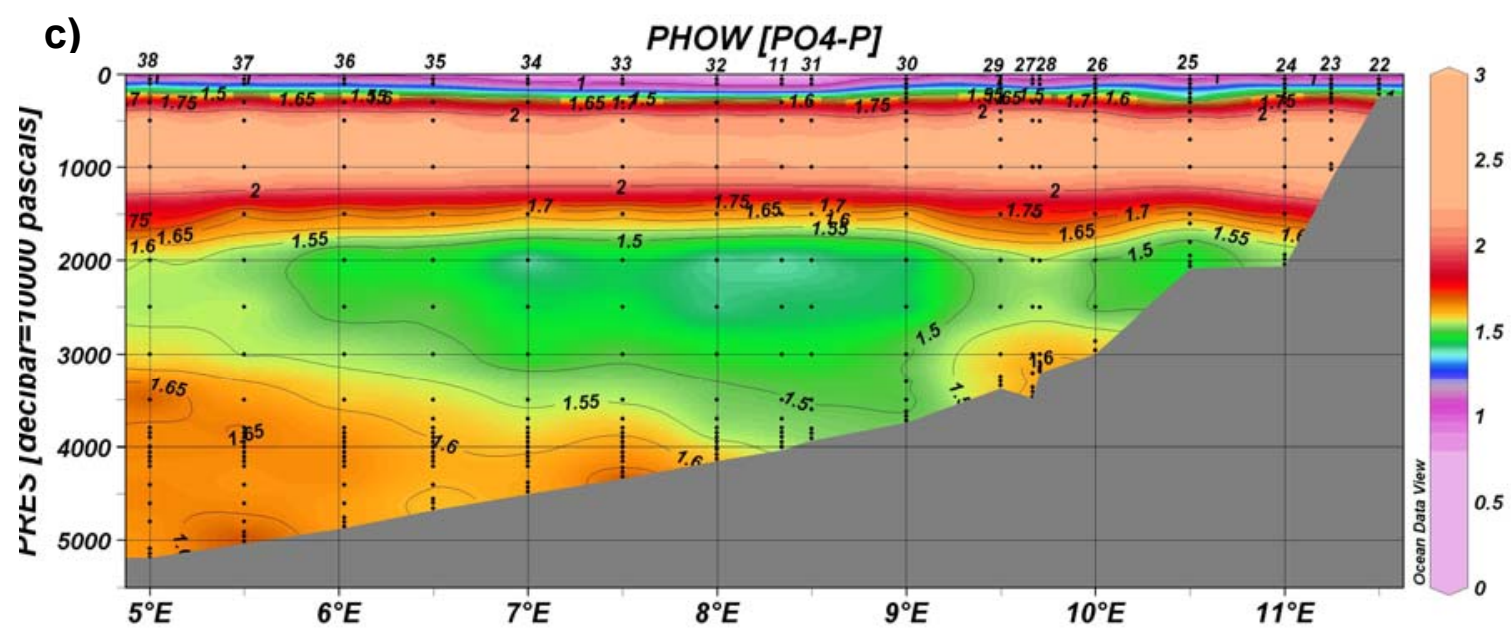




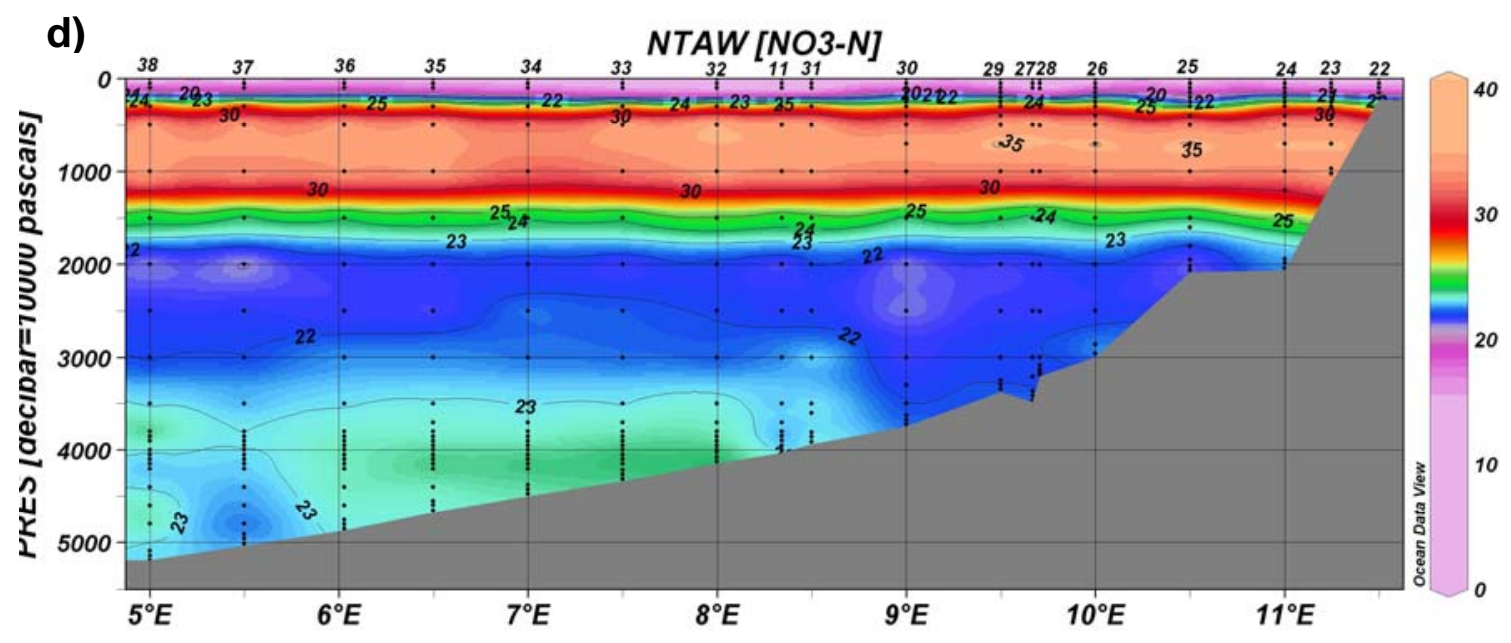




\section{Figure 8}

Vertical oxygen profiles for stations 38, 36 and 32 of Biozaire3 cruise. At station 32, the oxygen anomaly only appears on the very bottom at $4000 \mathrm{~m}$ depth. At station 38 , which is much deeper, this anomaly is shallower, separated from the bottom. At the station 36, just on the Congo lobe, a secondary anomaly appears also on the bottom
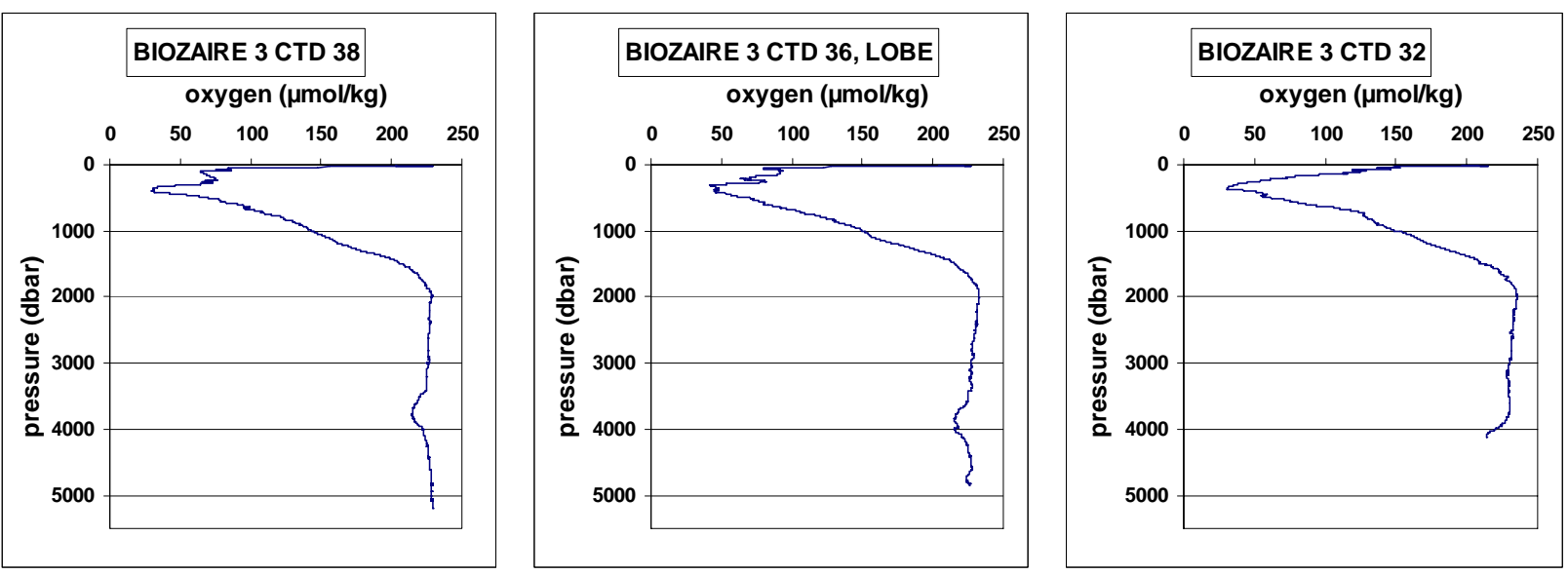


\section{Figure 9}

Typical pH profiles in the Gulf of Guinea. Stations 32 to 38 (western part of the studied area) have been selected since these particular stations showed significant $\mathrm{pH}$ drops near the bottom, in contrast with other stations where $\mathrm{pH}$ decreased smoothly toward the bottom.

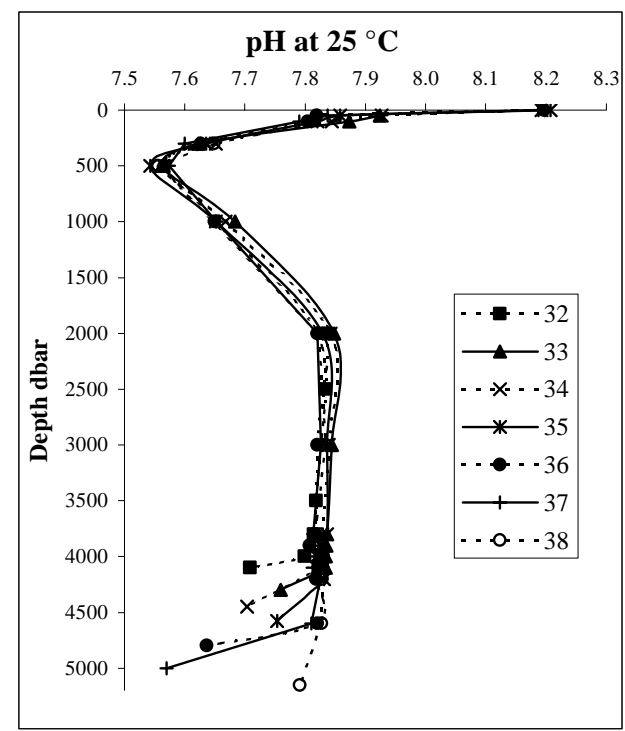


Figure 10

Oxygen and nutrient distribution on the north-south section along approximately $4000 \mathrm{~m}$ depth (south on the left). The colour scale, chosen to highlight the deep layer anomaly, is not linear Temperature and salinity vertical profiles are given below (a).

(a) Oxygen. (b) Silicate. (c) Phosphate. (d) Nitrate.

Drawn with ODV software Schlitzer, R., 2008 http://odv.awi.de.
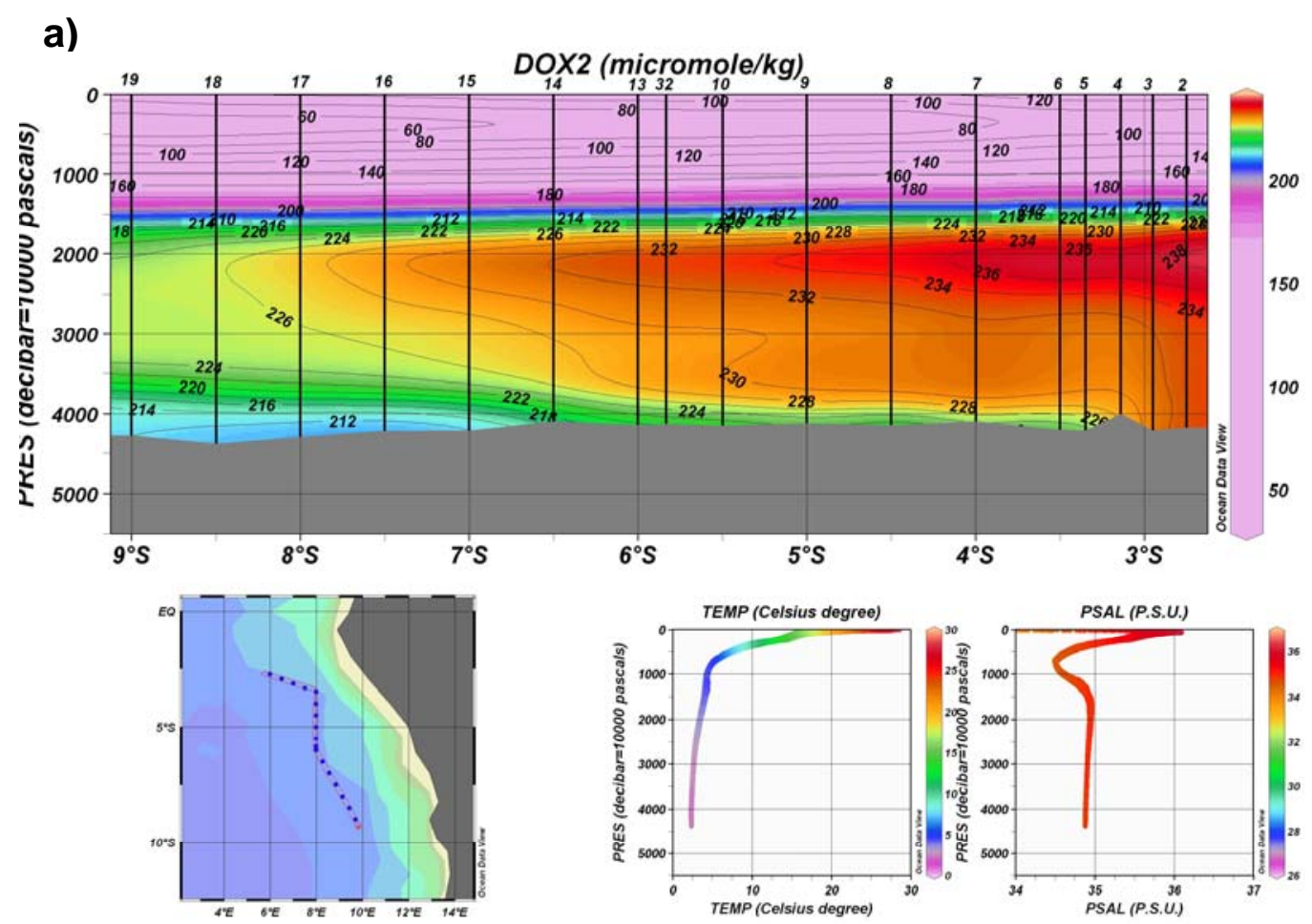


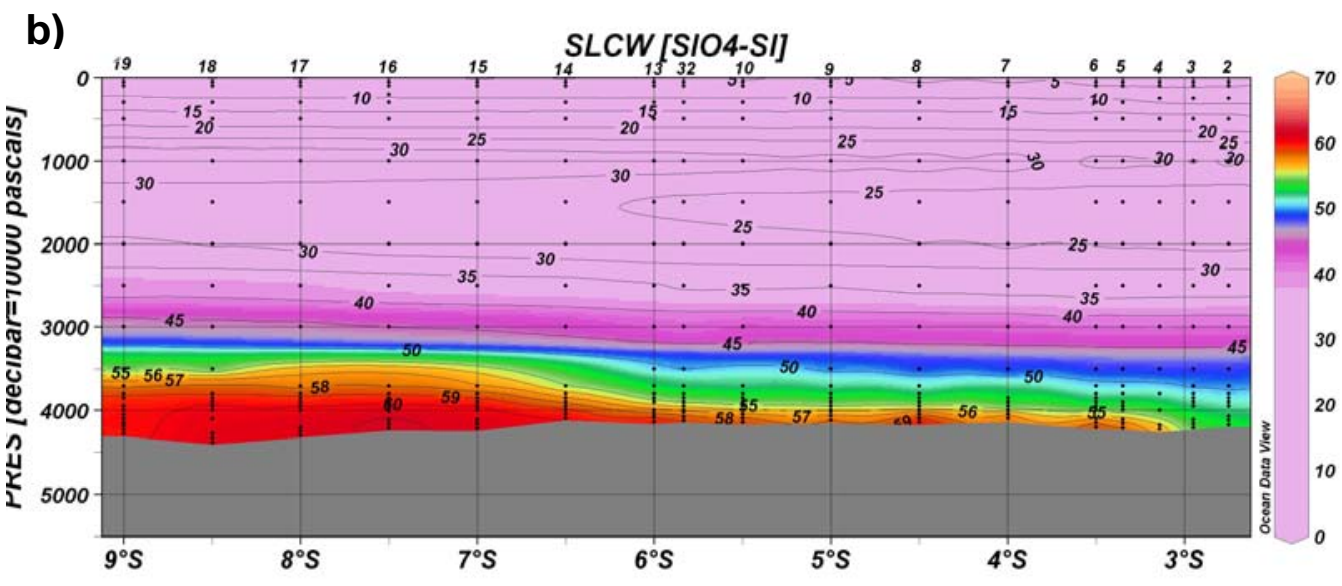




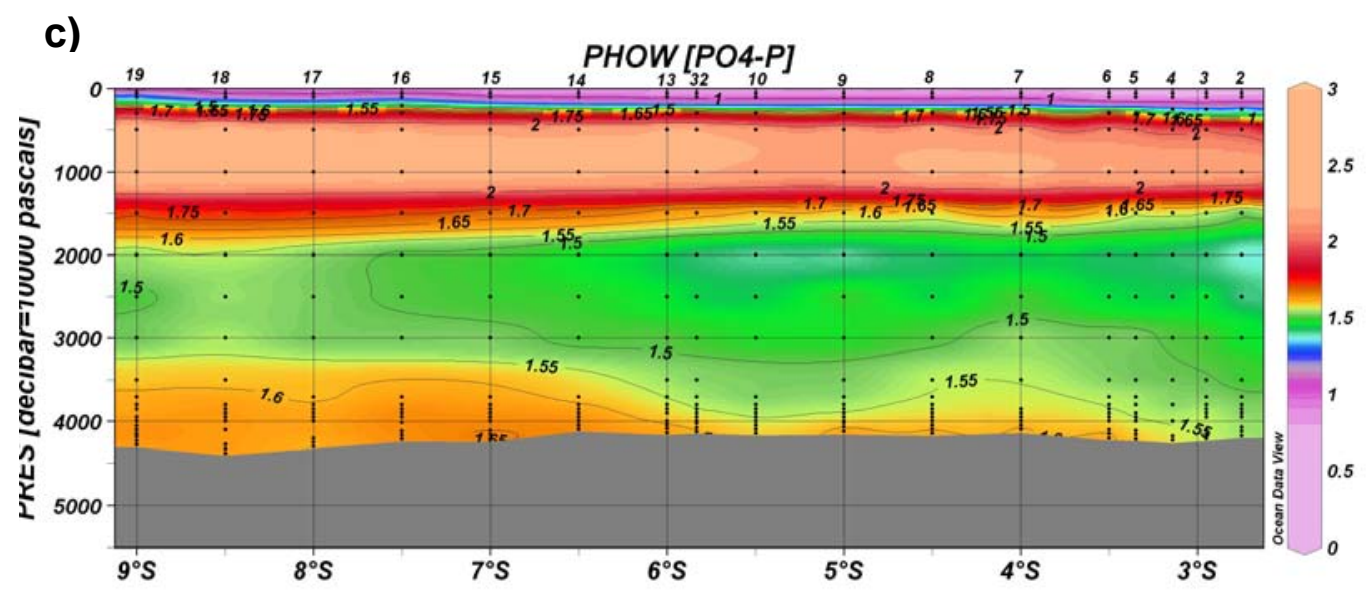




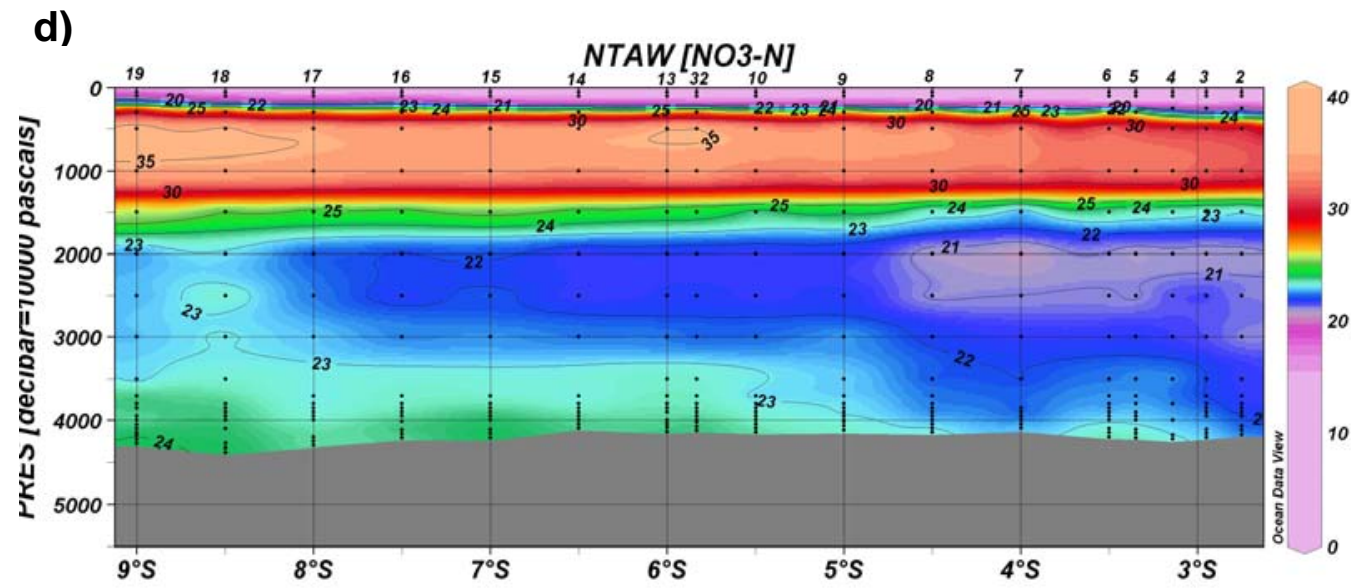


Figure 11 :

Vertical distribution of AOU (left), $\delta^{13} \mathrm{C}$ values of DIC (middle) and DIC (right) in the water column (0 to $5000 \mathrm{~m}$ ) in the Gulf of Guinea along the BIOZAIRE3 sections.
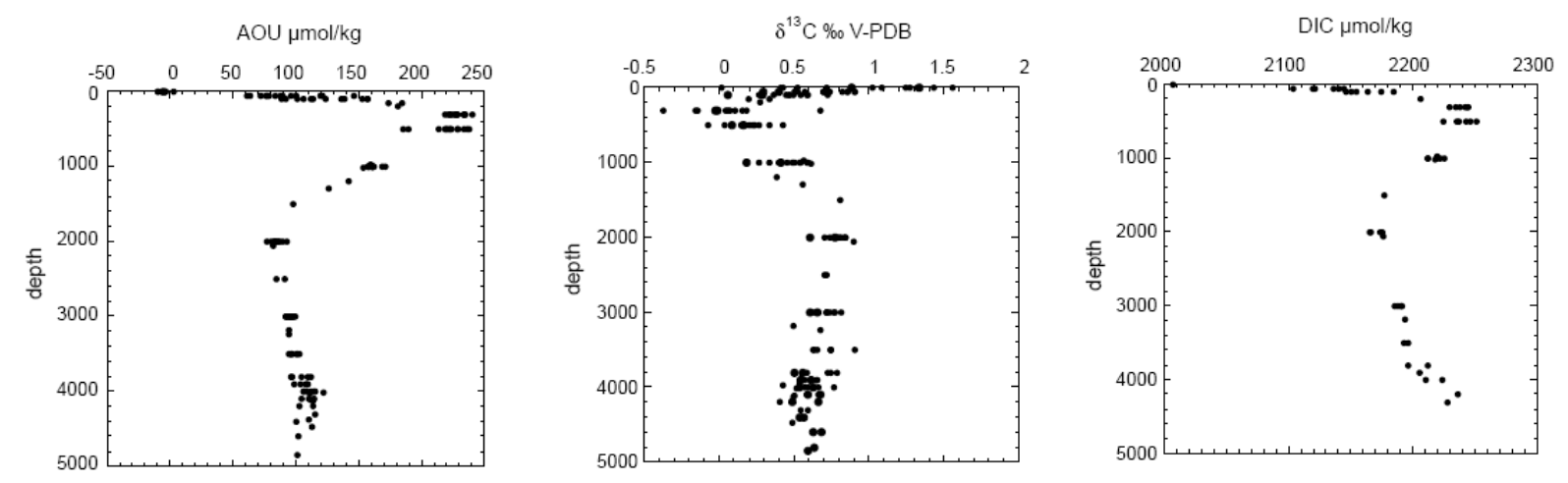
Figure 12

Relationship between $\delta^{13} \mathrm{C}$ values of DIC and DIC concentration in surface water and in the water column of selected stations of the Gulf of Guinea along the BIOZAIRE3 sections.

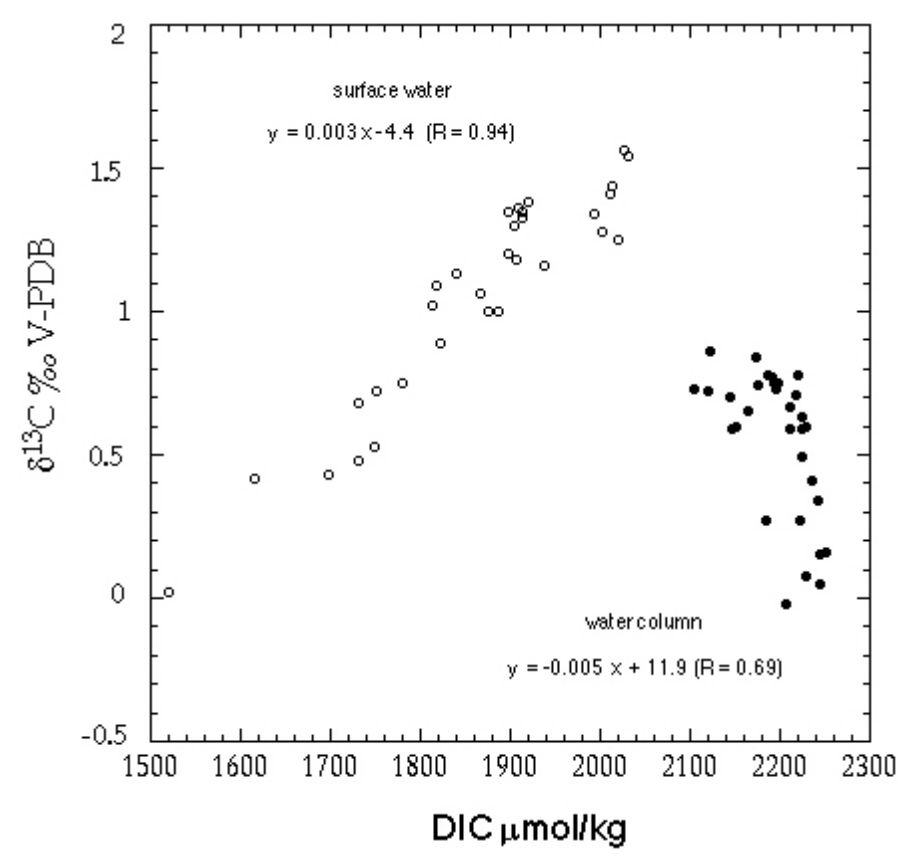

